Oriental Steelyards and Bismars

Author(s): H. Ling Roth

Source: The Journal of the Royal Anthropological Institute of Great Britain and Ireland, Vol. 42

(Jan. - Jun., 1912), pp. 200-233

Published by: Royal Anthropological Institute of Great Britain and Ireland

Stable URL: http://www.jstor.org/stable/2843237

Accessed: 18-12-2015 13:05 UTC

Your use of the JSTOR archive indicates your acceptance of the Terms \& Conditions of Use, available at http://www.jstor.org/page/ info/about/policies/terms.jsp

JSTOR is a not-for-profit service that helps scholars, researchers, and students discover, use, and build upon a wide range of content in a trusted digital archive. We use information technology and tools to increase productivity and facilitate new forms of scholarship. For more information about JSTOR, please contact support@jstor.org. 


\title{
ORIENTAL STEELYARDS AND BISMARS.
}

\author{
By H. Ling Roth.
}

Mr. Ivan Chien, of the Chinese Legation in London, informs me that, according to Chinese history, scales were first made in the reign of the Emperor $\mathrm{Fu} \mathrm{Hi}$, in the year 2956 B.C., but at the same time it is not thought that steelyards are here referred to. Chinese steélyards are mentioned by Europeans almost from their first contact with China. Friar Gasparda Cruz (died A.D. 1570) mentions that "Everyone that goeth to buy in the market, carrieth a weight \& balance, \& broken silver, and the balance is a little beame of Ivorie with a weight hanging at the one end with a string \& on the other end a little scale, and the string of the weight runneth along by the beame, which hath his markes from one Conderin to ten, or of one Maes unto ten" (Hakluyt, Glasgow ed., vol. xi, p. 507).

In the Sloane Collection in the British Museum (purchased by Act of Parliament in 1753) there is a steelyard $315 \mathrm{~mm}$. long, which Sloane purchased from a Dr. Cowell, with the following description, the date of which, judged by the handwriting, is about 1650 to 1680 :-

"To weigh with ye Japan Stilliards.

"When ye scale is to ye left hand; yn weighing with ye string next ye right hand 36 of ye uppermost pinns weigh 1 Tola, 72 weigh 2 Tolas, so yt each pin weighs $1 / 3$ of a Mase, a Tola being 12 Mase.

"Then weighing with ye middle string, the 4 of ye pins before you weigh 1 Tola, 16 weigh 2 Tolas, and so for every 12 pins 1 Tola.

"Then weighing wth ye string next yo $\mathrm{r}$ left hand, the first pin before you weighs 14 Tolas, $3 \frac{1}{2}$ weigh 15 Tolas 7 weigh 16 Tolas, and so for every $3 \frac{1}{2}$ one Tola more."

It is probably one of the earliest instructions as to how the weighings are carried out, and if not quite correct is quite clear, and shows what the unit is. Quite recently a French traveller has given us the following description, which is as follows :-

"In Burmese Laotia as in China they make use of a little steelyard (Romaine) with three fulcrums and hence with three different scales, of which the first descends to fens and stops at 5 hongs; the second goes from 5 hongs to 20 hongs giving the thes; the third goes from 20 hongs to 64 hongs and gives the hongs. These little balances can therefore weigh more than 2 kilogrammes of silver." (Fr. Garnier, Voy. d'Expl., Paris, 1873, ii, p. 344.) 
As a matter of fact there are very few travellers or residents in China who do not refer to the steelyard. J. F. Davis (The Chinese, chap. xxii), Gutzlaf (i, p. 23), Carne (Indo-China, London, 1872, p. 246), Otto E. Ehlers (i, p. 246, Indo-China), and a host of others speak of it. But, curiously enough, it is not mentioned in Ball's Guide (T'hings Chinese, 4th ed., London, 1904).

Diego de Pantala (1602), in writing of the Chinese, refers to the weighing of silver and says: "They cut it \& weigh it in certayne fine Weights like the Romane Weights in our Country; \& therefore everybody that will buy or sell, carryeth one of those Weights with them." (Purchas, Glasgow ed., xii, p. 374.)

The Chinese and Japanese steelyard in its simplest form consists of a beam, to which at one end a pan is attached, provided with a bob for suspension and a line of dots which indicate the weight measured.

The beams of nearly all the smaller steelyards are of bone, ivory, cane, or bambu; they are thicker at the fulcrum end, tapering down to the other end, and are marked with one or more lines of dots for indicating the weight, but not numbered, although there is in the British Museum (Fig. 8, Plate XXIV-this and other British Museum specimens are reproduced by the kind permission of Sir Hercules Read) an old one with an old label, marked " probably Italian," which is numbered from 5 to 110 . They are provided with a metal pan supported by four strings, seldom three, four strings being apparently easier to set up than three, and also of greater efficiency in so far as strength is concerned; they are also provided with a weight hanging by string or hair or silk from the beam, generally spoken of as the travelling poise, from the fact that it is moved to right or left in ascertaining the weight of the article. The steelyards when in use are held by the thread and bob at the fulcrum of the respective line of dots (the scale) it belongs to.

Chinese steelyards are mostly furnished with two or three lines of dots, and every such scale has its corresponding fulcrum. The steelyards are rarely supplied with one scale and fulcrum only; in fact, Mr. I. Chien, above mentioned, writing under date of December, 1900 , tells me that "It is said that some steelyards are made with one fulcrum only, but I have not seen them yet, although I have travelled a good deal in my country." Since Mr. I. Chien wrote I have obtained a couple of Japanese steelyards with one scale and fulcrum each (Fig. 3, Plate XXIII). There is no difficulty in supplying three scales to one steelyard; there is space for a fourth, and a fourth might be added, but it does not seem desirable, for by means of the third line of dots or scale the limit of its weighing capacity is probably reached. A fourth scale would be difficult to read, for, generally speaking, the :scales are placed as nearly on top as possible, so as to make the reading easily accessible and to save unnecessary handling. For instance, the scales on the :steelyard Fig. 6, Plate XXIV, are fixed at the following distances from each other: :scales 1 and 2, 4.5 mm. apart; scales 2 and $3,4.5 \mathrm{~mm}$.; and scales 3 and $1,16 \mathrm{~mm}$. apart, the larger bare space being the underside of the beam. It is not advisable to tempt the strength of the beam or strings by putting on the full weight which the steelyard will measure theoretically. The object of the series of two or three 
lines of dots or scales and corresponding fulcrums is to enable the user to weigh up to the full capacity of the steelyard. In the scales illustrated in Fig. 8, Plate XXIV, the cyphers indicate that the lowest scale weighs up to 10 units, the top scale from 10 to 50 units, and the middle scale from 50 to 110 units, and it is usuàl for the scales to overlap slightly. For instance, a steelyard will weigh from 0 grammes. up to 185 grammes ( $=5$ tahils) on the first scale; from 185 to 735 grammes.

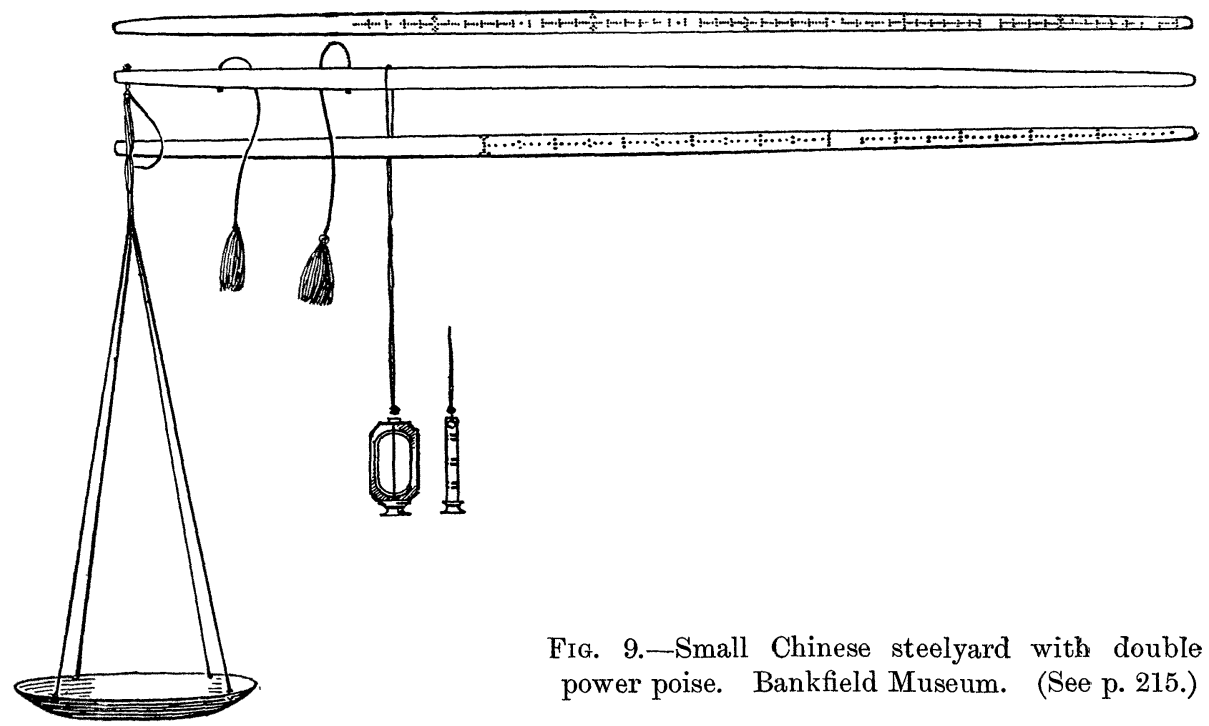

( $=20$ tahils) on the second scale ; and from 735 to 1208 grammes (=2 katis) on the third scale. Consequently with the three scales the weight of an article weighing up to 1208 grammes can be taken, while if the steelyard were provided with the first scale only, then 185 grammes only could be measured off. The second and third scales could, of course, be the only scales if the smaller weights were not required. But if one intends to use a steelyard it may as well be arranged to weigh to its fullest

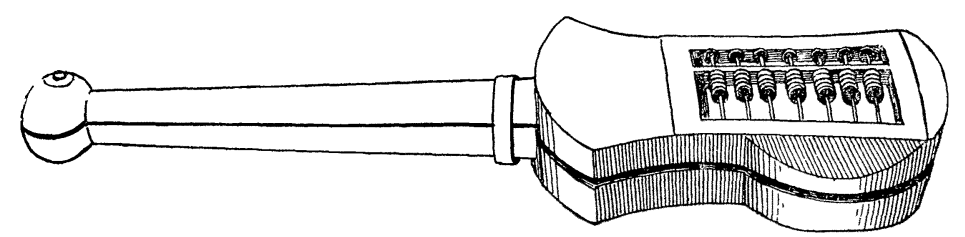

FIG. 10.-Chinese steelyard with abacus in the lid. Length $245 \mathrm{~mm}$. British Museum.

capacity, especially as to do this merely necessitates an additional scale with its corresponding fulcrum. Beyond this, in order to extend the capacity for measuring a minute quantity and still to keep up the capacity to weigh as large a quantity as the steelyard will carry, a compound weight has been introduced. This will be described later on. Naturally, the greater the weight to be measured the stronger must be all the parts of the steelyard, and hence, like our balances, the steelyards are made of various sizes and strengths. 
The whole fits into a case of solid wood or bambu, which is carried stuck in the waistband, although occasionally allowed to hang therefrom. (See Figs. 10 and

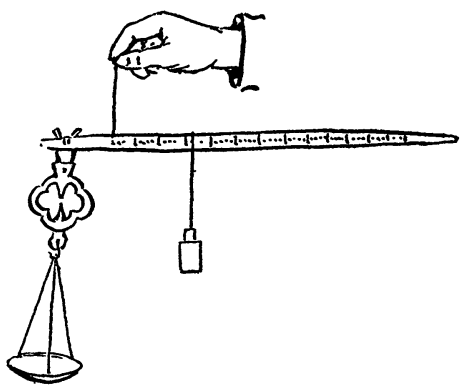

Fig. 11.-Jeweller's steelyard in J. Moura's Cambogia, Paris, 1883, vol. i, 369.

12 to 17.) The case is usually fan-shaped, or perhaps, more correctly speaking, in its outward appearance it resembles the Maori mere, and consists of two parts riveted together at one end. The upper part, the lid, is flat on the inside, and the lower part or bed, which holds the steelyard, is dug out for that purpose. Some cases are fiddle-shaped, and I have two Japanese cases which are of trapezoidal form (Fig. 17). In an example in the British Museum an abacus is fitted into the lid (Fig. 10) and sometimes the case is arranged to hold a large and a small steelyard side by side (Fig. 14). The British Museum has also a specimen in which a middle bed is placed between the lid and lower bed to hold a second steelyard which thus rests above the one in the bottom

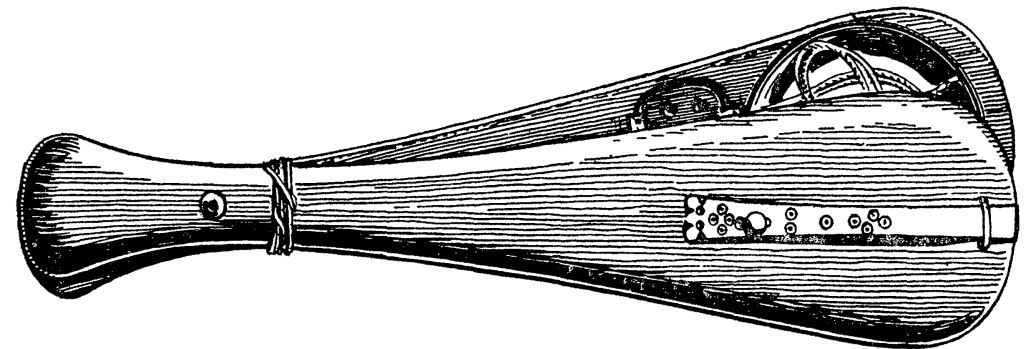

Fig. 12.-Case of compound steelyard illustrated in Fig. 1, Pl. XXIII, and Fig. 6, Pl. XXIV (for details see Figs. 18 and 19). Upper Burma.

(Fig. 13). The lid is not raised to open, but is pushed aside, being provided with a pivot for that purpose (Fig. 18), and when shut it is locked by a sliding bolt on the lid, the bent point of which fits into a slot in the lower part (Fig. 19).

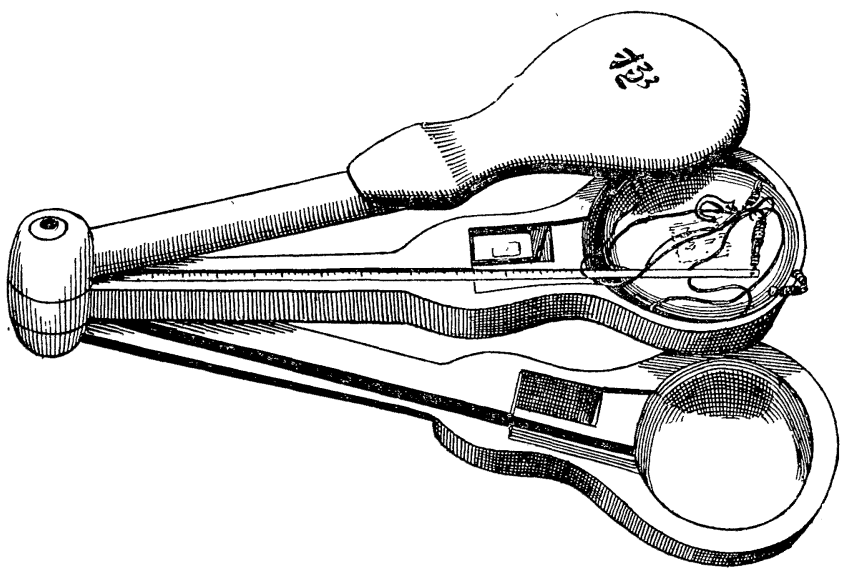

FIG. 13.-Fiddle-shaped case with two separate beds with a steelyard in each. Chinese. Length of case $290 \mathrm{~mm}$ British Museum. 


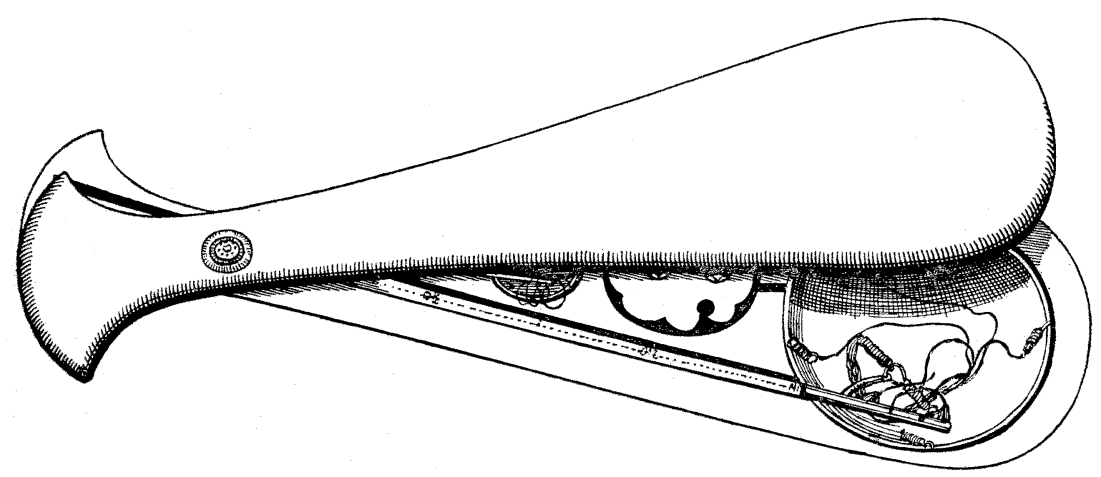

Fig. 14.-Case containing two steelyards in one bed. Length of case $430 \mathrm{~mm}$. Chinese. British Museum.

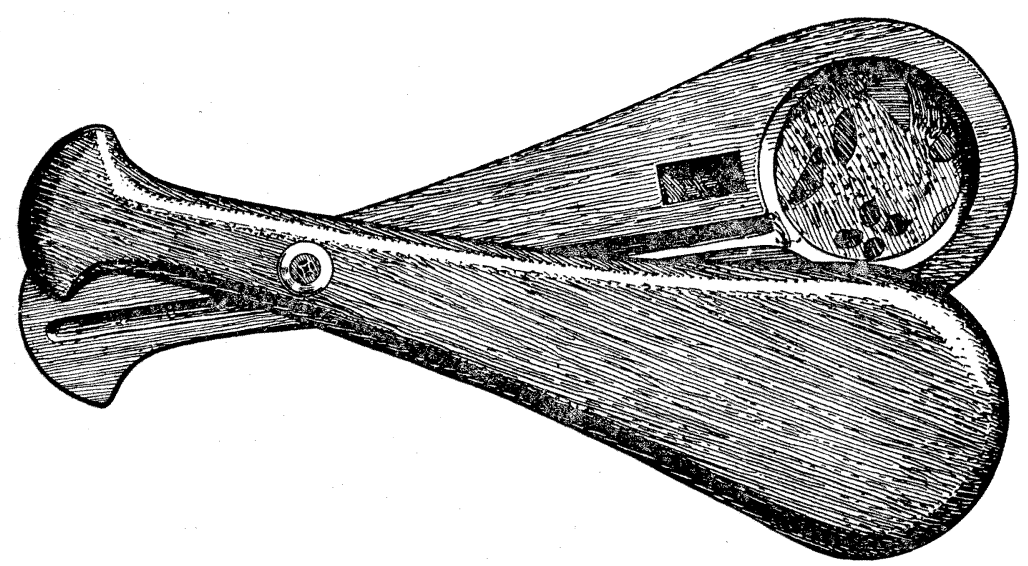

Fic. 15.-Case of steelyard, Fig. 7, Pl. XXIV. Chinese. Bankfield Museum.

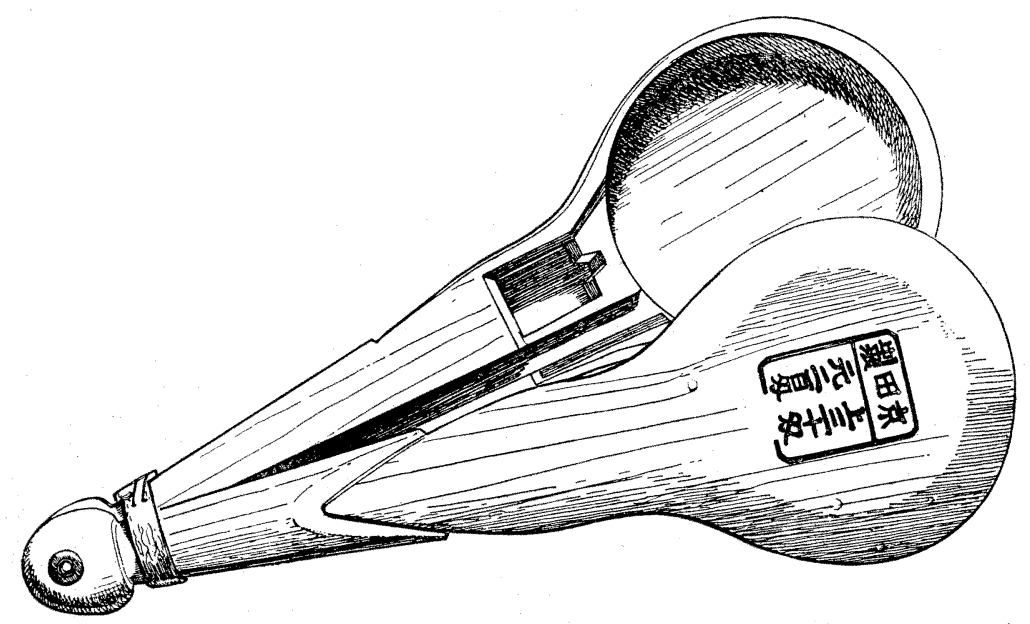

Frg. 16.-Case of steelyard, Fig. 2, Pl. XXIII. Chinese. Bankfield Museum. 
All the pans I have seen are circular. The weights, while mostly flat, vary very much in shape as well as in size.

The dots for the scale are made by drilling minute holes in the beam, inserting fine red copper wire and filing it off. But this insertion of fine copper wire is only done to the larger steelyards and not to the small ivory or bone ones, which are carried about one's person, in which, while the dots may be drilled to a very shallow degree, some black matter has been rubbed in. The Reverend Arthur H. Smith, the well-known missionary, and author of Chinese Characteristics, informs, me that " the dots are called stars, and the scale maker is termed a star fixer. The

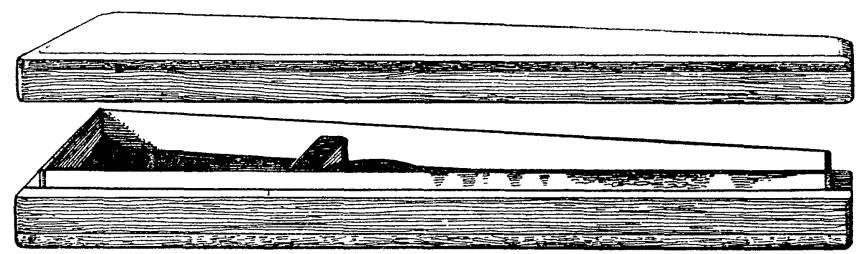

FIG. 17.-Case of Japanese steelyard with tortoiseshell pan. Bankfield Museum.

steelyard maker perambulates the street and puts in little dots according to the preferences of each customer, who will have not less than two sets of balances (i.e., separate steelyards), one for buying and one for selling. There are often many grades, and it is easy to confuse costumers not up to small 'deceits and sinful games." I myself cannot draw any evidence from these steelyards which would confirm the statement that one scale is for buying and one for selling. There is, no doubt, great confusion owing to this irresponsible method of fitting the scale (line of dots), for Captain W. Gill, after getting his silver weighed at Tien-Tsin, and that, with a great deal of trouble, tells us : "In travelling about from one city to another

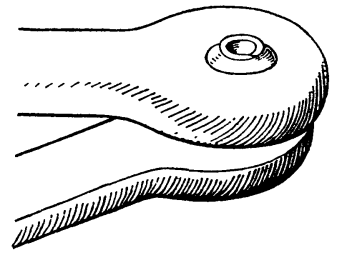

FIg. 18.-Details of case Fig. 12.
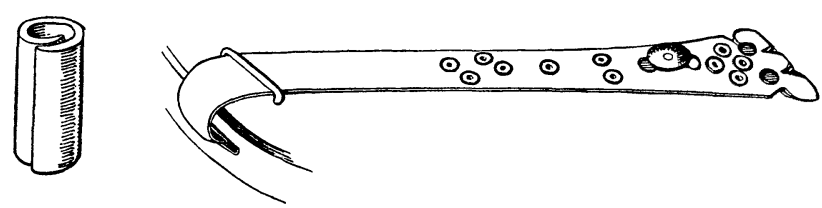

FIG. 19.-Details of case Fig. 12.

there is a further difficulty to be overcome, for every place has its own scale, and what is an ounce in one town will perhaps be less than an ounce in the next, so that the weary traveller, after having, as he thought, finally concluded the tiresome transaction, is quietly told that his scale is not a good one and the silver must all be weighed afresh in a balance of the place." (River of Golden Sand, London, 1880, i, pp. 45 and 46.)

With this little introduction we may now proceed to examine the steelyards individually. 
In Fig. 2, Plate XXIII, is illustrated a very beautifully finished steelyard of Chinese make with Government test marks. The length of the bone beam is $226 \mathrm{~mm}$.; diameter of pan, $80 \mathrm{~mm}$. ; poise $(\mathrm{P})=38.677$ grammes.

Fulcrum furthest from Pan.

(Scale No. 1.)

P. at 0 dots $=$ Equilibrium.

\begin{tabular}{|c|c|c|c|c|}
\hline 50 & $"$ & $=$ & $18 \cdot 5$ & nmes. \\
\hline , 100 & $"$ & $=$ & $37 \cdot 2$ & " \\
\hline 150 & " & $=$ & $55 \cdot 5$ & ", \\
\hline 200 & " & $=$ & $74 \cdot 5$ & , \\
\hline 250 & $"$ & $=$ & $93 \cdot 2$ & " \\
\hline 300 & 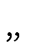 & $=$ & $112 \cdot 0$ & \# \\
\hline
\end{tabular}

Fulcrum nearest to Pan.

(Scale No. 2.)

P. at 0 dots $=112 \cdot 0$ grammes.

, $20,=185.0$,

" $70, \quad=373.0 \quad$,

" $120,=560.0$,

" $170,=748.0 \quad$,

The unit for the first scale is thus $0.373(112 \div 300)$ which means that for every dot the increase or decrease is about one-third of a gramme $=1$ hun. For the second scale the unit is $37.4(748-112=636 \div 170)=1$ tahil or one hundred times as much as that of the first scale. The second scale commences where the first leaves off. The first weighs up to 3 tahils (4 oz. avoirdupois) and the second up to 17 tahils or 1 kati and 1 tahil ( $\left.1 \mathrm{lb} .6 \frac{2}{3} \mathrm{oz}.\right)$.

It is in every way a very good steelyard, and probably as perfect as it is possible to make this class of instrument. The throwover arrangement for changing from one line to the other is ingenious-the fulcrum is changed, but the pan is not to be unhooked.

The case is shown in Fig. 16, p. 204.

Fig. 7, Plate XXIV, illustrates a steelyard from Shanghai; it is quite modern, nicely finished, with ivory beam and weight suspended by horse hair.

Length of beam, $280 \mathrm{~mm}$; diameter of pan, $61 \mathrm{~mm}$; poise $(\mathrm{P})=23.371$ grammes.

$$
\begin{aligned}
& \text { Fulcrum at A. (Scale No. 1.) } \\
& \text { P. at } 0 \text { dots }=\text { Equilibrium. } \\
& " 10,=3.5 \text { grammes. } \\
& \text {, } 100,=34.7 \quad \text {, } \\
& \text {, } 200, \quad=73.2 \quad,
\end{aligned}
$$

Fulcrum at B. (Scale No. 2.)

P. at 0 dots $=72.5$ grammes.

$$
\begin{array}{lll} 
& 10, & =109 \cdot 5
\end{array},
$$

The second scale does not commence exactly where the first leaves off. The unit for scale No. 1 is $73.2 \div 200=0.366$ and the scale is evidently intended to weigh up to 2 tahils ( $75^{\circ} 6$ grammes). For scale No. 2 the unit is $363 \cdot 1-72.5$ $=290 \cdot 6 \div 80=3 \cdot 63$, and the scale weighs up to, roughly, 10 tahils ( 378 grammes).

On scale No. 1, curiously enough, the point of equilibrium is nine points to the right of the fulcrum instead of equilibrium commencing with the first dot of the scale, confirming the statement as to the arbitrary way in which scales are put on.

The shape of the case, which is of a dark brown wood, is similar to that shown in Fig. 15, p. 204. 
There is another steelyard in the collection identical in almost every respect with the above, which weighs up to 73.2 and 365.5 grammes respectively, with a $\mathrm{P}=22 \cdot 891$ grammes.

A cheap form of Chinese steelyard (not figured) has the following dimensions :Bone beam, $263 \mathrm{~mm}$. long; diameter of pan, $66 \mathrm{~mm}$. ; poise $(\mathrm{P})$ a crude flat oval piece of brass $=9 \cdot 010$ grammes.

Fulcrum furthest from Pan.

(Shortest Scale.)

P. at 0 dots $=$ Equilibrium.

, $50,=3.75$ grammes.

$, 100,=7 \cdot 5$,

, $150,=11 \cdot 2$,

, $200, \quad=15.0$,

"250, = 18.75 ,

$300,=22.55$,

$350,=26.4$,
Middle Scale.

(Scale 2.)

P. at 0 dots $=24.9$ grammes. , $25,=33.0$,

, $50, \quad=43.5$

, $75,=52 \cdot 0$

, $100, \quad=61 \cdot 2$

$, 125,=70 \cdot 2$

$, 150,=79 \cdot 7$
Fulcrum nearest to Pan.

(Scale 3.)

P. at 0 dots $=64: 5$ grammes.

, $50, \quad=104.5$,

, $100,,=145 \quad$,

$, 150,,=184 \quad$,

For the shortest scale the unit is $26.4 \div 350=0.75$ and the scale will weigh up to about $7 \mathrm{chi}$; for the middle scale the unit is $79 \cdot 7-24 \cdot 9=54 \cdot 8 \div 130=0.365$, and the scale will weigh up to a little over 2 tahils; for the longest scale the unit is $184-64 \cdot 5=119 \cdot 5 \div 150=0 \cdot 79$. For the first scale it will weigh up to $\mathrm{P} \times 3$; for the middle scale $\mathrm{P} \times 9$, and for the third scale $\mathrm{P} \times 20$.

The case is crudely cut out of bambu and is fiddle shaped.

The weighings on a second popular form of Chinese steelyard closely resembling the above works out as follows :-

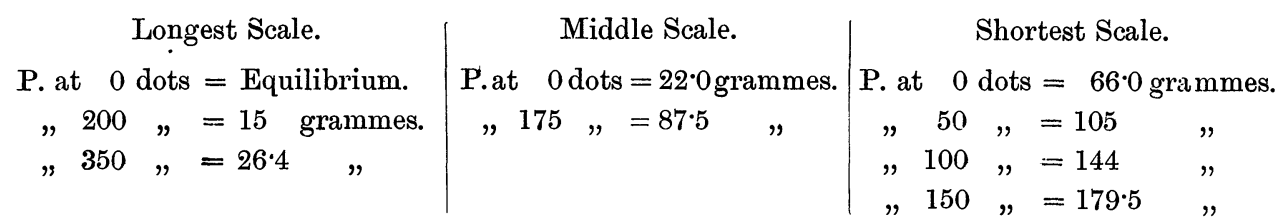

The units are thus respectively $0.754,0.374$, and 0.756 .

The weighings on a third cheap Chinese steelyard are as follows :-

Long Scale.

P. at 0 dots $=$ Equilibrium.

, $200 "=15 \cdot 0$ grammes.

" $350, \quad=26 \cdot 2 \quad$,
Short Scale.

P. at 0 dots $=18$ grammes.

\begin{tabular}{|c|c|}
\hline 50 & $=37$ \\
\hline 150 &,$\quad=75$ \\
\hline
\end{tabular}

The units being respectively 0.754 and 0.38 . The short scale of this steelyard differs, however, from all the others in the fact that after a series of 10 divisions of 5 dots each there is suddenly a change to 5 divisions of 5 dots each, the 5 divisions together taking up as much space as the 10 together. (See Fig. 23, p. 210.)

On looking back over the results it may be stated that the principle appears 
to be that every dot should represent two huns or one hun, i.e., 0.756 or 0.378 grammes.

We have also in the collection a Chinese steelyard (not figured) from UpperBurma, much worn, and with every appearance of age. The bone beam is $310 \mathrm{~mm}$. long ; diameter of pan, $82 \mathrm{~mm}$.; poise $(\mathrm{P})=95.911$ grammes.

\begin{tabular}{|c|c|c|c|c|c|c|c|c|c|c|c|c|}
\hline \multicolumn{4}{|c|}{ Shortest Scale. } & \multicolumn{4}{|c|}{ Middle Scale. } & \multicolumn{5}{|c|}{ Longest Scale. } \\
\hline at & $0 \operatorname{dots}=$ & 0.0 & ammes. & P. at & $0 \mathrm{dc}$ & ts $=185$ & mmes. & P. at & & $\operatorname{lots}=$ & $738 \cdot 0$ & mmes \\
\hline 5 & $50, \quad=$ & $=19 \cdot 5$ & $"$ & " & 10 &,$=222$ & $"$ & $"$ & 1 & $=$ & $769 \cdot 2$ & $"$ \\
\hline 25 & $50, "=$ & $=93 \cdot 0$ & $"$ & 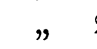 & 25, &,$=277$ & 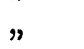 & 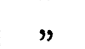 & 5 & $\eta=$ & $932 \cdot 0$ & " \\
\hline 50 & $00, y=$ & $=185^{\circ} 0$ & ״ &, 1 & 150 &,$=735$ & ״ & " & 15 & $\eta=$ & $=1320^{\circ} 0$ & , \\
\hline
\end{tabular}

For the shortest scale the unit is $185 \div 500=0.37$ per dot, and the scale will weigh up to 5 tahils. For the middle scale the unit is $735-185=550 \div 150=$ $3 \cdot 66$, and the scale weighs up to over $1 \frac{1}{5}$ kati. For the longest scale the unit is $1,320-738=582 \div 15=38 \cdot 8$, and weighs up to $2 \frac{1}{5}$ kati. It will weigh $\mathrm{P} \times 2, \mathrm{P} \times 8$, and $\mathrm{P} \times 14$, approximately, per respective scale.

The case is black lacquered and very old; the poise is very crude and filed out of a piece of brass (Fig. 20).

A steelyard similar to the above three specimens, but provided with an equilibrium indicator, comes from Taiping in the Malay Peninsula, but it is Chinese. It has a bone beam and the same poor finish as the commoner sorts above described. The indicator is similar to that shown in Fig 11, p. 203.

When equilibrium is indicated the beam is not horizontal, but is tilted upwards at an angle of about ten degrees $\left(10^{\circ}\right)$. Mr. Leonard Wray, from whom I obtained this specimen, informs me that this peculiarity is common to nearly all the Chinese-made

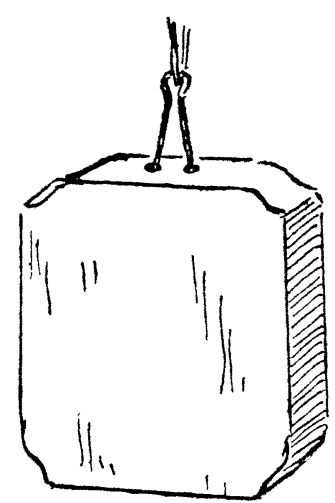

Fia. 20.-Poise of Chinese steelyard. Bankfield Museum. steelyards in the Peninsula.

Length of beam, $250 \mathrm{~mm}$; diameter of pan, $65 \mathrm{~mm}$.; poise $(\mathrm{P})=7.052$ grammes.

With Fulcrum furthest from Pan.

(Shortest Scale.)

P. at 0 dots $=$ Equilibrium.

, $50, \quad=3 \cdot 7$ grammes.

$" 150,=11 \cdot 1 \quad$,

" $250,=18.5 \quad$,

$" 350,=25 \cdot 8 \quad$ "
With Middle Fulcrum.

(Medium Scale.)

P. at 0 dots $=21$ grammes.

$$
\begin{aligned}
& " 50, \quad=39 \quad, \\
& " 100, \quad=58 \\
& " 150,=76 \text { " }
\end{aligned}
$$

With Fulcrum nearest to Pan.

(Longest Scale.)

P. at 0 dots $=68$ grammes.

$\Rightarrow \quad 50 \quad,=105 \quad "$
$" 100 \quad=142 \quad "$
$" 150 \quad=180 \quad$,

For the first scale the unit will be $25 \cdot 8 \div 350=0 \cdot 737=2$ huns, and the scale weighs up to $7 \mathrm{chi}$; for the middle scale the unit will be $76-21=55 \div 150=$ $0 \cdot 366=1$ hun, and the scale weighs up to 1 tahil ; for the third scale the unit, 
will be $180-68=112 \div 150=0 \cdot 746=2$ huns and the scale weighs up to 5 tahils.

In Fig. 22 I have illustrated a steelyard from the Federated Malay States ; it is nicely finished and provided with equilibrium indicator (as shown in Fig. 11), which when it indicates equilibrium has the beam at an angle of about $10^{\circ}$ above the horizontal; its dots or stars are of brass wire. It appears to have been tested by Government officials.

Length of wood beam, $690 \mathrm{~mm}$. ; diameter of brass pan, $164 \mathrm{~mm}$. ; poise $(\mathrm{P})=$ 1,512 grainmes.

Fulcrum furthest from Pan.

(Shortest Scale.)

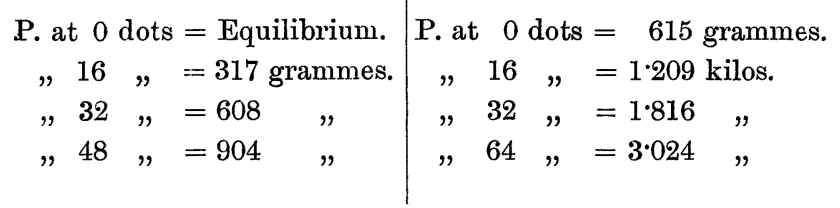

Fulcrum in Centre.

(Middle Scale.)
Fulcrum nearest to Pan.

(Longest Scale.)

P. at 0 dots $=3 \cdot 049$ kilos.

$$
\begin{aligned}
& \text { " } 2 \text { " }=3.660 \text { " } \\
& \text { " } 4 \text { " }=4 \cdot 284, \\
& \text { (" } 20, \quad=9 \cdot 209 \text {, }
\end{aligned}
$$

The unit for the shortest scale is $904 \div 48=18 \cdot 8$, and it will weigh over $1 \frac{1}{2}$ katis (907 grammes); the unit for the second scale is $3,024-615=2,409 \div 64=37 \cdot 6$, and it will weigh over 5 katis ; the unit for the third scale is $4,284-3,049=1,232 \div$ $4=308 \cdot 7$, and it will probably weigh up to 15 katis (but I cannot get that quantity of weight into the scale). The unit for the third scale does not appear to be neither a fraction nor a multiple of a hun $(0.378$ gramme), but it is nearly half a kati or 8 tahils (302.4 grammes), which is 800 huns, and therefore a multiple of a hun, which it is probably intended to be.

The first (shortest) scale on Fig. 22, see Fig. 22A, begins with twenty dots divided into fives, which take up the same space as eight of the immediately succeeding dots and continue thus, so that what I have named dot 16 is really dot 28, and what I have named dot 32 is really 44; I have treated the scale as though the first 20 dots were 16 only. For the space occupied by the 20 dots, the unit is 158 grammes, more like a Japanese measure, being almost equal to $100 \mathrm{shu}=156.5$ grammes.

We now come to two Japanese steelyards, Fig. 3, Plate XXIII, purchased in Yokohama, and said to be used for pharmaceutical purposes ; both are provided with trapezoid shaped cases, Fig. 17 ; they have bone beams, tortoiseshell pans, each with three silk strands for support.

Length of beam, $152 \mathrm{~mm}$; diameter of pan, $48 \mathrm{~mm}$; poise $(\mathrm{P})=1 \cdot 127$ grammes. The scale is also divided into fives and tens.

$$
\begin{aligned}
\text { P. at } 0 \text { dots } & =\text { Equilibrium. } \\
\Rightarrow 10, & =0.39 \text { gramme. } \\
\Rightarrow 20, & =0.72 \quad,
\end{aligned}
$$

$$
\begin{aligned}
& \text { P. at } 40 \text { dots }=1.36 \text { grammes. } \\
&, \quad 60 \quad, \quad=1.98
\end{aligned}
$$

The unit $=1.98 \div 60=0.033$ per dot. It looks as though the unit were VOL. XLII. 

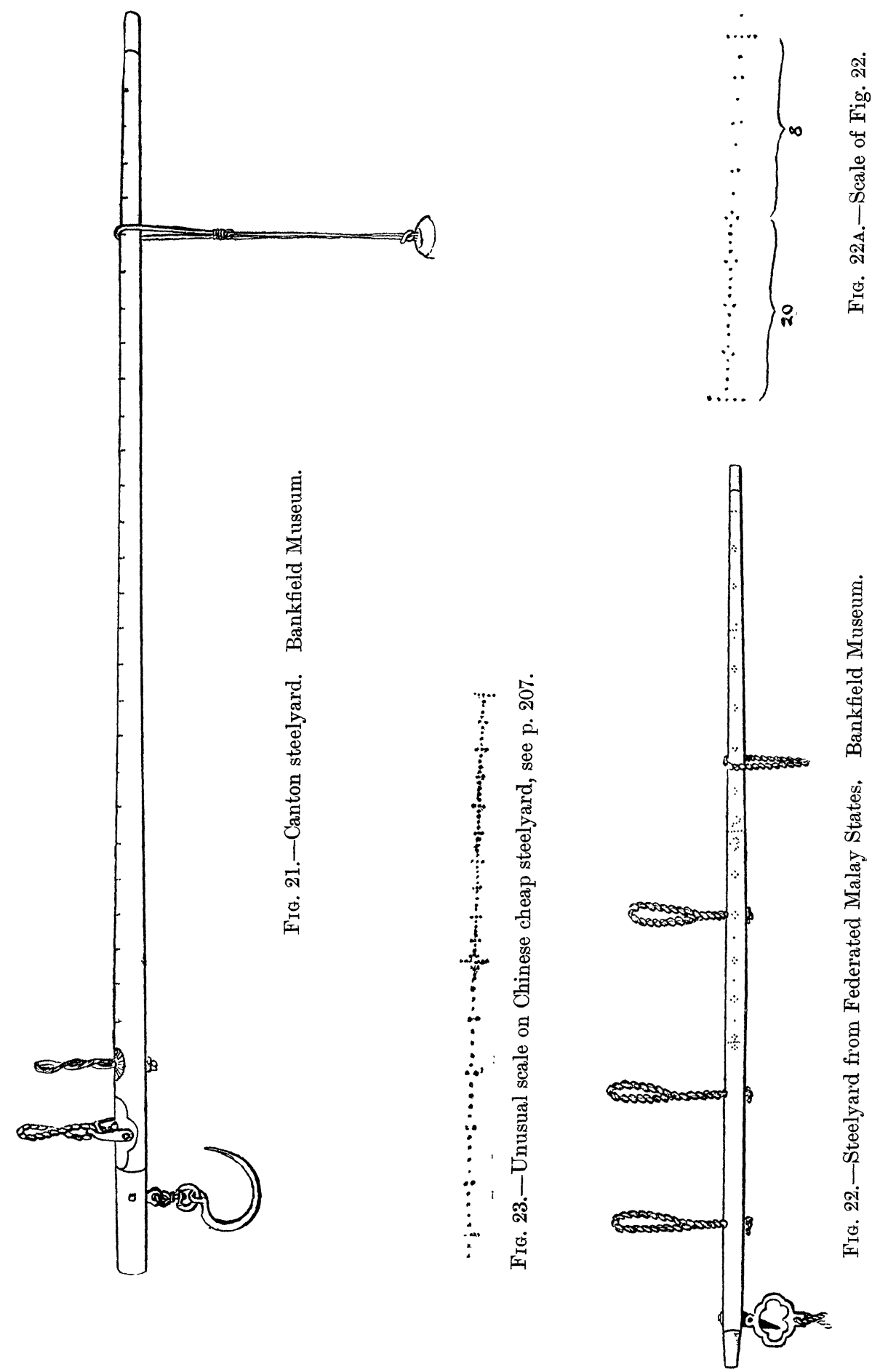
intended to represent a tenth of a mommé for ten dots $=0.39$ gramme, and the whole scale was intended to weigh up to five mommé $=1.87$ grammes.

Similar to the above is another steelyard, but smaller in every way. The length of beam is $140 \mathrm{~mm}$.; diameter of pan, $42 \mathrm{~mm}$; poise $(\mathrm{P})=0.481$ grammes. The scale is also divided into fives.

$$
\begin{aligned}
& \text { P. at } 0 \text { dots }=\text { Equilibrium. } \\
& \text {, } 10, \quad=0.17 \text { gramme. } \\
& \text { P. at } 25 \operatorname{dots}=0.37 \text { gramme. } \\
& \text {, } 50,=0.72 \text {, }
\end{aligned}
$$

The unit is $0.72 \div 50=0.0144$. Five divisions (=25 dots) weigh 0.37 grammes, or one-tenth of a momme, and the whole scale appears to weigh up to one-fifth of a mommé.

Professor W. Gowland, F.R.S., informs me that this type is unknown to him, and as the steelyards are intended to weigh such small quantities they were evidently used for medicines. He also says that in his time " the portable steelyards which were in use for weighing gold and silver had generally two points of suspension and two scales, and the weight placed on the beam weighed 10 mommé. The beam was of bone or ivory.

"When the poise was used with one of the suspenders and placed at 0 , the beam was in equilibrium. Each division of the scale $=\frac{1}{10}$ mommé, and the scale was graduated up to 15 mommé.

"When the poise was used with the other suspender and placed at 0 it required 10 mommé to counterbalance it. Each division of the graduated scale $=\frac{1}{5}$ mommé and the graduation went up to 50 mommé."

These gold and silver scales are therefore the same in principle as the Chinese ones described above. It seems a clear deduction from the table of weights that the Japanese metrology is derived from the Chinese, and hence the close correspondence in the steelyards.

The steelyard illustrated in Fig. 1, Plate XXIII, comes from Upper Burma. It differs from those of its class in being provided with a compound weight. It consists of the usual bone beam and brass pan and has three scales. Its poise is made up of two pieces of brass, a large and a small piece, which fit together, but while the small piece can be used by itself, the large one can only be used with the small one. The large poise $(\mathrm{P})$ is a flat ovoid having six shallow concavities on the front and four on the back. It has a hole $(4 \mathrm{~mm}$. diameter) drilled right through from top to bottom, connected with the front by a slot which runs parallel to the full length of the hole. At the lower end of the poise a rectangular piece has been cut out. The small poise ( $p)$, which consists of a rectangular block of brass, is provided with a long slender lug, the top of which has been pierced for the suspending string. This small poise fits into the large one, and when the two poises are to be put together the string is slipped through the slot so as to save the labour of pushing it up through the hole.

The length of the case is $388 \mathrm{~mm}$. over all. Weight of pan about 33 grammes ; weight of beam, 28.5 grammes; total weight of pan, beain, and strings, 61.5 , say 
62 grammes. Diameter of pan, $90 \mathrm{~mm}$; diameter of beam, $7.5 \mathrm{~mm}$., tapering to $6.5 \mathrm{~mm}$. ; length of beam, $306 \mathrm{~mm}$. Total movable poise with strings $=50.2$ grammes $=\mathrm{P}+\mathrm{p}=$ double power. Small movable poise with strings $=6.0$ grammes nearly $=\mathrm{p}=$ single power. String $=$ about 0.2 gramme. Large poise $(\mathrm{P})=44 \cdot 2$ grammes. The full-sized drawing of the beam is seen in Fig. 6, Plate XXIV, Nos. 1, 2, and 3.

B. Point of attachment of pan. C, D, E. Three fulcrums with string and bobs for holding the steelyard when weighing. G. Centre of gravity of beam with bobs. N. Point of commencement of second scale No. 2. R. Point of commencement of third scale No. 3 .

Fulcrum at C. (Scale No. 1.)

p.

At F. 0 dots $=456$ grammes $=\mathrm{p} \times 76$

\begin{tabular}{|c|c|c|c|c|}
\hline T. 10 & " & 509 & $"$ & $=p \times 85$ \\
\hline K. 20 & $"$ & 551 & $"$ & $\begin{array}{r}\times 2 \\
\times \quad 2\end{array}$ \\
\hline L. 30 & " & $=601$ & " & $p \times 100$ \\
\hline
\end{tabular}

The unit $=601-456=145 \div 30=4 \cdot 83$

$$
\begin{aligned}
& p+P . \\
& 741 \text { grammes }=(\mathrm{p}+\mathrm{P}) \times 14 \cdot 7 \\
& 1,134 "=\quad \times 22.6 \\
& 1,517, \quad=\quad \times 30.2
\end{aligned}
$$

The unit $=1,517-741=776 \div 20=38 \cdot 8$

\begin{tabular}{|c|c|c|c|c|}
\hline , H. 10 & ” & $=141 \cdot \tilde{\mathrm{o}}$ & $"$ & $=\mathrm{p} \times 23.6$ \\
\hline " K. 20 & " & $=158.0$ & " & $=p \times 26.3$ \\
\hline L. 30 & $"$ & $=174 \cdot 0$ & $"$ & $=\mathrm{p} \times 29$ \\
\hline
\end{tabular}

Fulcrum at D. (Scale No. 1.)

p.

At E. $0 \operatorname{dots}=125 \cdot 0$ grammes $=\mathrm{p} \times 21$

$$
\begin{aligned}
& p+P \text {. } \\
& =205 \text { grammes }=(\mathrm{p}+\mathrm{P}) \times 4 \cdot 1 \\
& =341 \quad, \quad=\quad, \quad \times 6.8 \\
& =481 \quad, \quad=\quad, \quad \times 9.5 \\
& =620 "=\quad, \quad \times 12.3 \\
& \text { The unit }=620-205 \div 30=13 \cdot 8
\end{aligned}
$$

Fulcrum at E. (Scale No. 1.)

p.

At E. 0 dots $=0$ grammes $=p \times 0$

, H. $10, \quad=6 \quad, \quad=\mathrm{p} \times 1$

"K. $20 "=12 \quad " \quad=p \times 2$

"L. $30, \quad=18 \quad, \quad=\mathrm{p} \times 3$

The unit $=18 \div 30=0 \cdot 6$

$$
\begin{aligned}
& \mathrm{p}+\mathrm{P} \text {. } \\
& =0 \text { grammes }=(\mathrm{p}+\mathrm{P}) \times 0 \\
& =50.2, \quad=\quad, \quad \times 1 \\
& =98.0 "=\quad \times 2 \\
& =148.0 "=\quad, \quad \times 3 \\
& \text { The unit }=148 \div 30=5
\end{aligned}
$$

Fulcrum at C. (Scale No. 2.) 420 grammes in pan to produce equilibrium without weight.

p.

At N. 0 dots $=454=\mathrm{p} \times 76$

, O. $50,=519=\mathrm{p} \times 86.5$

$"$ P. $100, \quad=569=\mathrm{p} \times 95$

The unit $=569-454 \div 100=1 \cdot 15$

$$
\mathrm{p}+\mathrm{P} \text {. }
$$

696 grammes $=(\mathrm{p}+\mathrm{P}) \times 13.9$

$1,210 \quad=\quad \times \quad \times 24 \cdot 2$

The unit $=1,210-696 \div 50=10 \cdot 3$ 
Fulcrum at D. (Scale No. 2.) 115 grammes in pan produces equilibrium without weight.

p.

At N. 0 dots $=125$ grammes $=p \times 21$

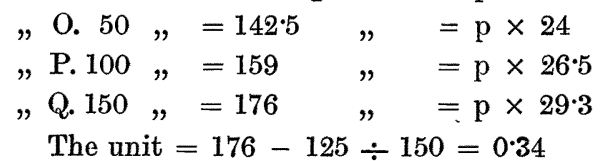

$$
p+\mathbf{P}
$$$$
=186 \text { grammes }=(\mathrm{p}+\mathrm{P}) \times 3.7
$$$$
=370 \quad, \quad=\quad \times \quad \times 7 \cdot 4
$$$$
=558 \quad, \quad=\quad, \quad \times 11 \cdot 1
$$

$=731 \quad, \quad=\quad, \quad \times 14.5$

The unit is $731-186 \div 150=3.63$

Fulcrum at C. (Scale No. 3.)

p.

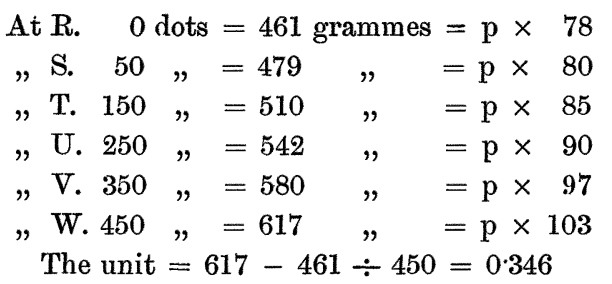

$$
p+P
$$

\begin{tabular}{|c|c|c|c|c|}
\hline 762 & & $=$ & & $\times 15$ \\
\hline 895 & ” & $=$ & " & $\times 17.8$ \\
\hline 179 & 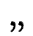 & $=$ & " & $\times 23.5$ \\
\hline & " & $=$ & " & $\times 29.4$ \\
\hline
\end{tabular}

The unit $=1,477-762 \div 250=2 \cdot 86$

Fulcrum at D. (Scale No. 3.)

p.

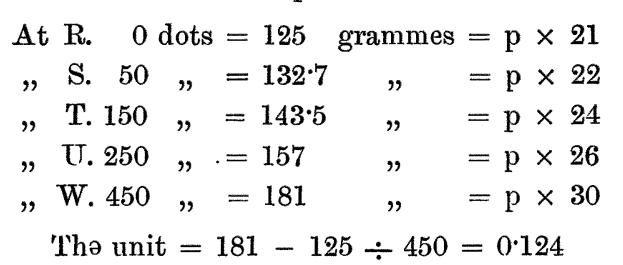

$$
p+P \text {. }
$$

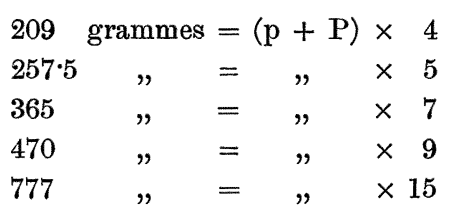

The unit $=777-209 \div 450=1 \cdot 25$

Fulcrum at E. (Scale No. 3.)

p.

At S. 50 dots $=2.7$ grammes $=p \times 0.45$
,
$=\mathrm{p} \times 1.25$
U. $250,=11 \cdot 5$
$=\mathrm{p} \times 2.0$
"W. $450,=20.4$
$=\mathrm{p} \times 3.6$

The unit $=20 \cdot 4-2 \cdot 7=17 \cdot 7 \div 450=0 \cdot 039$

$$
\begin{aligned}
& p+P \text {. } \\
& =19.0 \text { grammes }=(\mathrm{p}+\mathrm{P}) \times 0.39 \\
& =75.7 \quad=\quad \times 1.5 \\
& =93.5, \quad=\quad, \quad \times 1.8 \\
& =166.5 \quad, \quad=\quad \times 3.3
\end{aligned}
$$

The unit $=166 \cdot 5-19=147 \cdot 5 \div 450=0 \cdot 32$

The poises $\mathrm{p}$ and $\mathrm{p}+\mathrm{P}$ will, as a matter of course, at the various positions, like the simple poises of other steelyards, weigh a multiple of their own weight, but for practical purposes such measurements should be whole numbers only, and not fractions or decimals unless we except halves.

With scale No. 1, fulcrum E, both single and double power weigh out exact multiples of their own weight, but neither the weight at any given division nor the unit can be said to be in accord with any divisor of the Chinese measures. With the same scale and fulcrum $D$ we do not get whole numbers, neither again are the results recorded in Chinese measures. 
With the same scale, but fulcrum at $\mathrm{C}$, we have very similar results. While the single power weighs up to $1 \mathrm{kati}$, the unit is not a distinct Chinese measure, the nearest approach to 483 being $491=13$ tahils. It commences to weigh at 12 tahils and rises to $1 \mathrm{kati}$ (604 grammes), but the intermediate divisions at 10 dots and 20 dots give fractions which cannot be intended. For the double power it commences to weigh at 20 tahils, and as far as we dare risk its strength, it weighs up to 40 tahils (1,513 grammes); the unit is also 10 tahils, so that it seems with scale No. 1 and fulcrum $C$ the double power is intended to be used. On the other hand, we are met with the difficulty that the scale is not strong enough to carry much more than 1,500 grammes, while theoretically it should carry 500 more. With scale No. 2 the fulcrum at $\mathrm{E}$ is out of the question, and with the fulcrum at $\mathrm{D}$ or $\mathrm{C}$ we have similar anomalies as with scale No. 1 and double power, although with the fulcrum at $\mathrm{D}$ we get an approach to the Chinese measure in the result 363 , which is probably intended to represent $378=10$ tahils.

With scale No. 3 and any of the fulcrums C, D, or E, we have the same difficulty.

It is noteworthy that for the single power with the different scales and fulcrums there is no continuity at all, while there is continuity between scale No. 1, fulcrum E, double power, giving multiples of 1,2 , and 3, and scale No. 3, fulcrum $\mathrm{D}$, double power, giving multiples of 4 , 5, etc., up to 15 , and, perhaps, with scale No. 1, fulcrum C, double power, 15 to 30 .

There seems to be no simple ratio between the small power ( $p=6.0$ grammes) and the double power ( $\mathrm{p}+\mathrm{P}=50 \cdot 2$ grammes).

One of the objects of the double power seems to be that we can get a multiple of the weight used (expressed in the term of the Chinese measure of weight), while we do not get this with the use of the single-power poise.

The results of the double-power poises tabulate as follows :-

\begin{tabular}{l|c|c|c|c|c}
\hline & & \multicolumn{2}{|c|}{ Range (in Grammes). } & \multicolumn{2}{c}{ Unit. } \\
\hline $\begin{array}{c}\text { Fulcrum } \\
\text { at- }\end{array}$ & $\begin{array}{c}\text { Scale } \\
\text { No. }\end{array}$ & $\begin{array}{c}\text { Single Poise. } \\
\text { p. }\end{array}$ & $\begin{array}{c}\text { Double Poise. } \\
p+\text { P. }\end{array}$ & $\begin{array}{c}\text { Single Poise. } \\
\text { p. }\end{array}$ & $\begin{array}{c}\text { Double Poise. } \\
p+\text { P. }\end{array}$ \\
\hline C. & 1 & $456-601$ & $741-1,517$ & $4 \cdot 83$ & $38 \cdot 8$ \\
C. & 2 & $454-569$ & $696-1,210$ & $1 \cdot 15$ & $10 \cdot 3$ \\
C. & 3 & $461-617$ & $762-1,477$ & 0.346 & $2 \cdot 86$ \\
D. & 1 & $125-174$ & $205-620$ & $1 \cdot 63$ & $13 \cdot 8$ \\
D. & 2 & $125-176$ & $186-731$ & 0.346 & $3 \cdot 63$ \\
D. & 3 & $125-181$ & $209-777$ & $0 \cdot 124$ & $1 \cdot 25$ \\
E. & 1 & $0-18$ & $0-148$ & 0.6 & $5 \cdot 0$ \\
E. & 3 & $2 \cdot 7-20 \cdot 4$ & $19-166.5$ & 0.039 & 0.32 \\
\hline
\end{tabular}


It seems that the double poise is intended to continue on the same scale where the limit of the single poise is reached. Comparing the second and third columns of the table there is in most cases rather a considerable gap, but in as many instances the third column is evidently a continuation of the second, e.g., in the last five lines.

It is also evident that the range of weights covered on the three different scales is the same when the same fulcrum is used. For example, using fulcrum D and any of the scales we can use the steelyard for weights from 125-177 grammes; using $\mathrm{C}$ we can weigh from 454-1,517 grammes. With the three fulcrums we can weigh from $0-1,517$ grammes. There is some overlapping of weights between $\mathrm{C}$, $\mathrm{D}$, and $\mathrm{E}$, but not very much.

By referring to the units the object of having three scales covering the same range of weights can be seen. In each case the unit of the first scale is big compared with the unit of the second scale, and this is big compared with the third scale. So we should use the first scale for approximate weighings, and the second and third for more accurate work.

Take one or two examples. Suppose we wanted to get a big weight, approximately, use $\mathrm{C} 1$, double poise. To get the same weight accurately use C 3, double poise. For an accurate small weight use E 3, single poise, etc.

The smallest unit 0.039 might be intended for 1 ti, but there does not seem to be any obvious connection between the other units and the Chinese measures of weight.

In Fig. 9, p. 202, we have another illustration of a steelyard with a double power. It is a Chinese steelyard nicely finished, closely resembling the one illustrated in Fig. 7, Plate XXIV. The poises, although of a different form, are fitted together in the same method as in the steelyard, Fig. 1, Plate XXIII.

Length of beam, $166 \mathrm{~mm}$; diameter of brass pan, $38 \mathrm{rum}$.

Small brass poise $(p)($ with thread $)=0.532$ grammes.

Large brass poise $(\mathrm{P})$ (alone) $=\frac{4 \cdot 732}{5 \cdot 264} \quad$ "

$\mathrm{p}+\mathrm{P}$ (double power)

$=\overline{5 \cdot 264} \quad$,

or $\mathrm{p}+\mathrm{P}=10 \times \mathrm{p}$.

As in the other steelyard, the large weight is not used by itself, but only in conjunction with the small weight.

Scale No. 1.

p.

At $\quad 0$ dots $=$ Equilibrium.

” $50,=0.4$ grammes.

"250" $=1 \cdot 87$ "
$\mathrm{p}+\mathrm{P}$.

At 0 dots $=$ Equilibrium.

„ $50,=4.0$ grammes.

"250 \#= 18.5 ,

With $\mathrm{p}$ only the scale weighs up to 5 huns, and the unit is $1.87 \div 250=$ 0.0748 . With $\mathrm{p}+\mathrm{P}$ the scale weighs up to $5 \mathrm{chi}$, and the unit is 0.0748 . 
Scale No. 2.

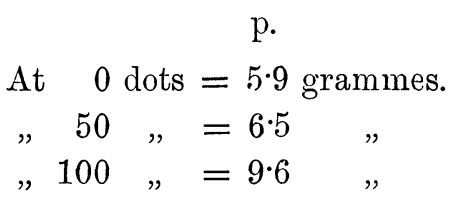

$\quad \mathrm{p}+\mathrm{P}$.
At $\quad 0$ dots $=18 \cdot 5$ grammes.
$\Rightarrow \quad 50 \quad, \quad=37 \cdot 0 \quad$,
$, 100 \quad,=55 \cdot 0 \quad$,

With the single power the scale weighs up to about $2 \frac{1}{2}$ chi, and the unit is 0.037 ; with the double power the scale weighs up to about $1 \frac{1}{2}$ tahils, and the unit is likewise 0.37 .

While with scale No. 1 the double power weighs ten times as much as the single power, with scale No. 2 the double power weighs about $5 \cdot 7$ times as much as $\mathrm{p}$ only, which is practically an impossible figure, and hence the conclusion may be drawn that $\mathrm{p}$ only is not intended to be used on scale No. 2.

In this steelyard, Fig. 9, we have, using the first scale, the single poise for weighing accurately up to 1.87 grammes - the unit being $0.00748\left(\frac{1}{5}\right.$ ti), and the double poise to continue the weighings up to 18.5 grammes, but not 80 accurately - the unit now being 0.0748 (or $2 \mathrm{ti}$ ). Using the second scale and the single poise we can get weights from 6-10 grammes accurately (unit=1 ti), and with the double poise we can continue with less accuracy up to 55 grammes (unit $=1$ hun).

A fancifully ornamented steelyard, illustrated in Fig. 24, comes from Upper Burma. Length of beam 1·14 metre. The scale is curiously divided, and I have not been able to get any explanation as to the reason of the division. It does not tally

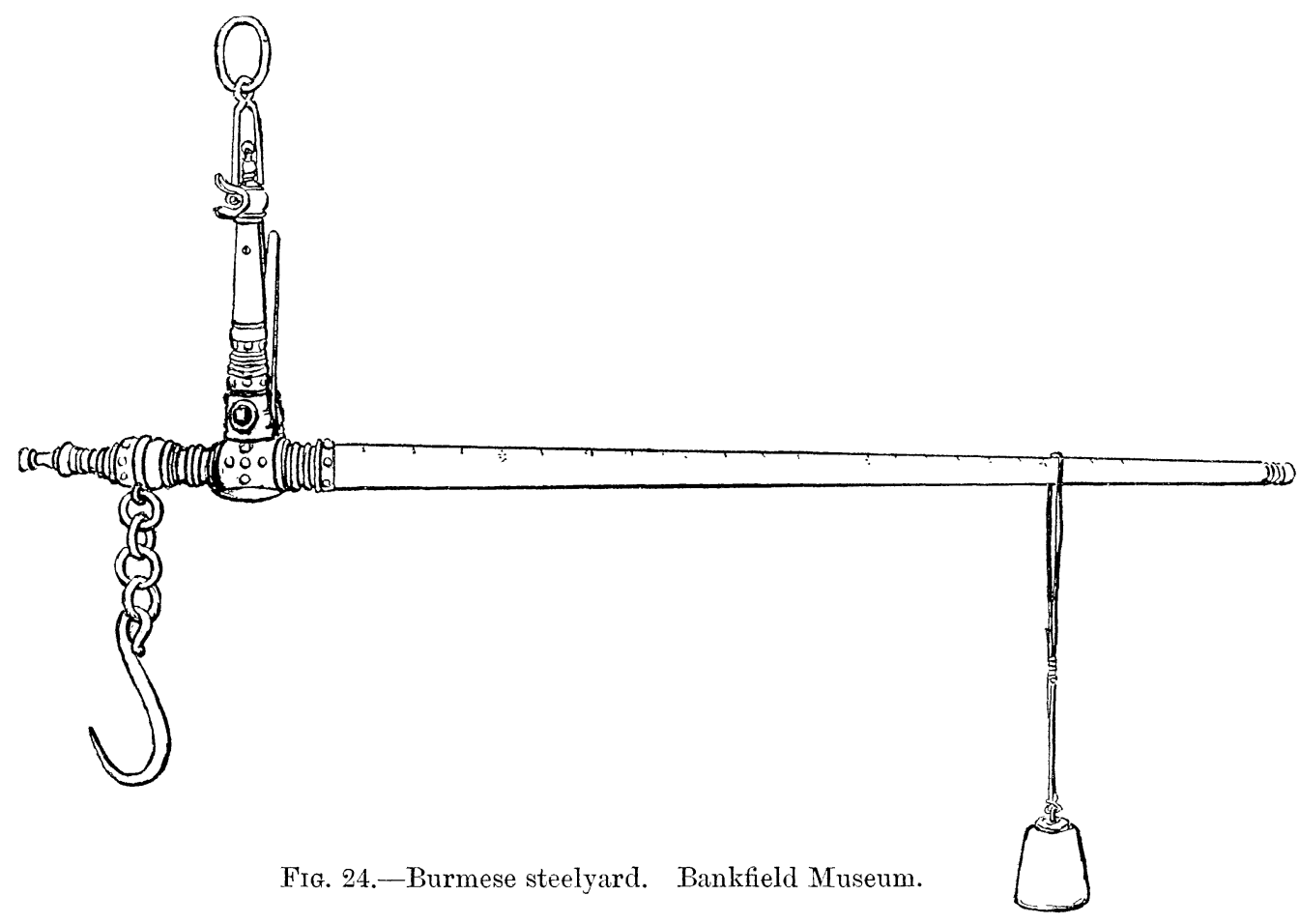


with Chinese measure. This scale, Fig. 25, consists of six large divisions divided into five lesser ones, and these are again divided into two smaller ones, which are lastly divided into two smallest, so that the main divisions are practically divided into twenty subdivisions. The beam is in equilibrium with 15 katis on the initial main division, and rises by 15 katis for each one, or 0.75 kati per smallest subdivision.

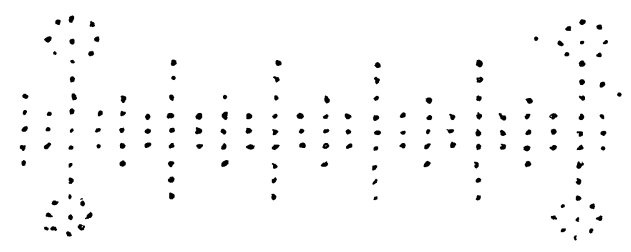

FIG. 25.-Scale on steelyard Fig. 24.

From Canton we have in Bankfield Museum a large steelyard, Fig. 21, p. 210, $1.80 \mathrm{~m}$. long, made of hard strong wood with one fulcrum of cord only, which perforates the beam and is fixed by a knot, and another fulcrum made of brass, which hinges on the beam. It is provided with two corresponding scales, and the unit is 1 and 5 katis respectively.

There is also at Bankfield a large steelyard from Perak, and like all the steelyards from that district, it is of Chinese make. It is of wood with brass caps at either end, but provided with iron fittings for the fulcrum as well as for the hook. The indicator is about 10 degrees out of the perpendicular, as in all others from the Malay Peninsula. It is Government stamped, and is marked 50, 100, 150 (katis), which is an innovation of recent years in steelyards. It is provided with two scales (rows of dots), one on each side, and exactly alike, so that the weight can be read off by any one standing on either side, and is a great improvement on the single row of dots, usually on top or as close to the upper side of the beam as possible.

Length of beam 1.70 metre.

It starts weighing at 50 katis and goes up to 200 katis, the unit being $200-50$ $=150 \div 150=1 \mathrm{kati}=604$ grammes.

Of the Malay steelyards, Mr. Wray informs me that they are made by Chinamen, and that before the year 1893, when the Malay weights were adjusted, they were also made by Chinamen. "The beams are made of a hard wood called mungapus or lengapus. They are not turned in a lathe, but are worked into shape by sawing the wood into lengths of square sections, then reducing these with an axe to nearly the size and shape intended and finished off with small planes, the blades of which are curved like those used in England for beadwork.

"The makers have standard weights, and the large divisions are marked off by their use, the smaller by subdivision. For instance, the maker puts a kati weight in the pan and slides the poise he intends to use with the particular steelyard to and fro until it balances. This gives the one kati mark. He then takes a 2-kati 
weight, and so gets the 2-kati mark. The space between these marks he divides into sixteen parts, which gives him tahils and so on.

"The beam having been marked out, a man takes it, and with the aid of a small pump drill makes a series of holes along the lines. This work is done very rapidly and skilfully, a few strokes up and down of the wooden crosspiece only being required for each hole. The holes are about $\frac{1}{8}$ inch $(3 \mathrm{~mm}$.) deep, and a short length of brass wire is driven into each hole with a light hammer, and cut off close. The whole is then finished off with a fine file."

Before leaving the steelyards I must call attention to a very curious one, Fig. 26, which has been in Bankfield Museum a long time, but the provenance of which is quite unknown, although it is evidently of Chinese origin. The beam and the hooks are of a very hard wood, apparently similar to that of the large Chinese and

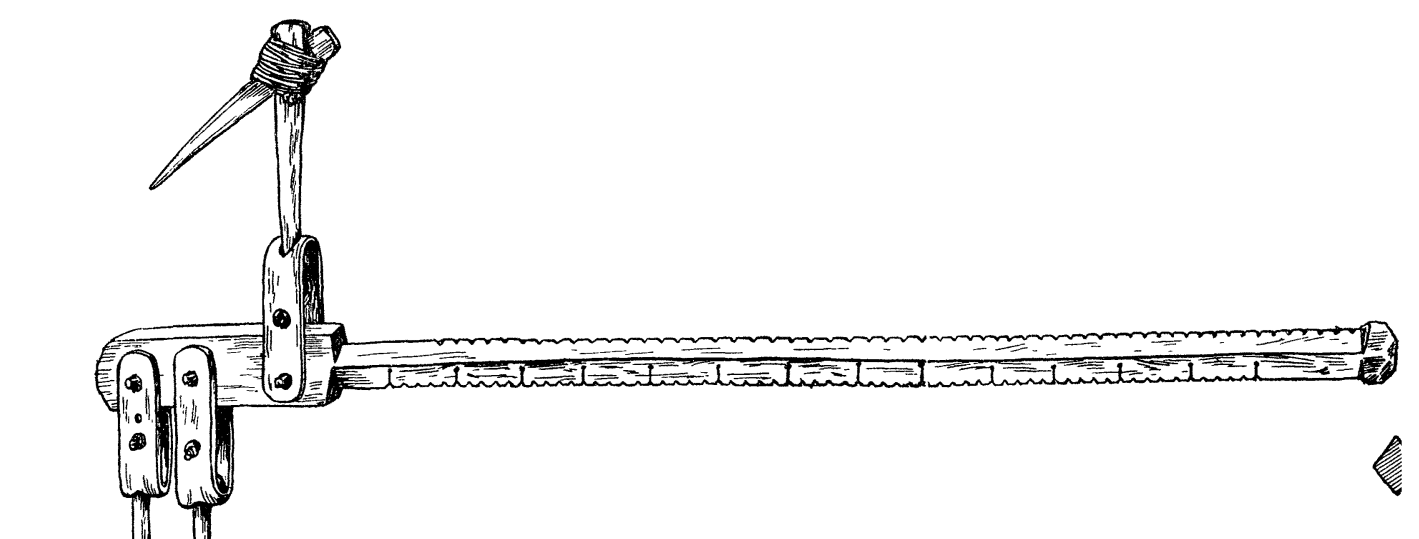

FIG. 26.-Oriental wooden steelyard fitted with greenhide and string. Bankfield Museum.

Malay steelyards. The beam is diamond shaped in section and has notches instead of the usually inserted brass dots, and the system is decimal; it is $520 \mathrm{~mm}$. long. The hooks are formed of two pieces of wood of unequal length tied together by cotton string at the thicker end, at an angle of about $45^{\circ}$; at the end of the longer piece there is a knob which has been pushed through a hole cut into the middle of a strip of greenhide. This must have been done when the greenhide was still new and flexible. The greenhide is bent double, and the two arms thus formed are attached to the beam by a small tough wooden pin which goes right through the beam. Above the pin the two arms are joined by a very thin strip of greenhide, to prevent their spreading out and slipping off the pin. There is no pan and no poise with it-both missing.

The fulcrum for both scales is placed below the level of the pin of the hook 
on which the load is placed, and hence equilibrium is so unstable that it is quite impossible to weigh anywhere approximately correct, and there is a further difficulty in the friction which exists between the greenhide and the pins. But in so far as I could manage it, with the scale marked with the notches wider apart, it starts with 1 kati and weighs up to 4 katis at the 60 th notch, so that the unit would be $4-1=3 \div 60=0.05$, or if we take the larger divisions, of which there are six, it would be half a kati for every one. This steelyard in use would be a splendid instrument if anyone wants a, what a Yorkshireman understands by the word, "fratch."

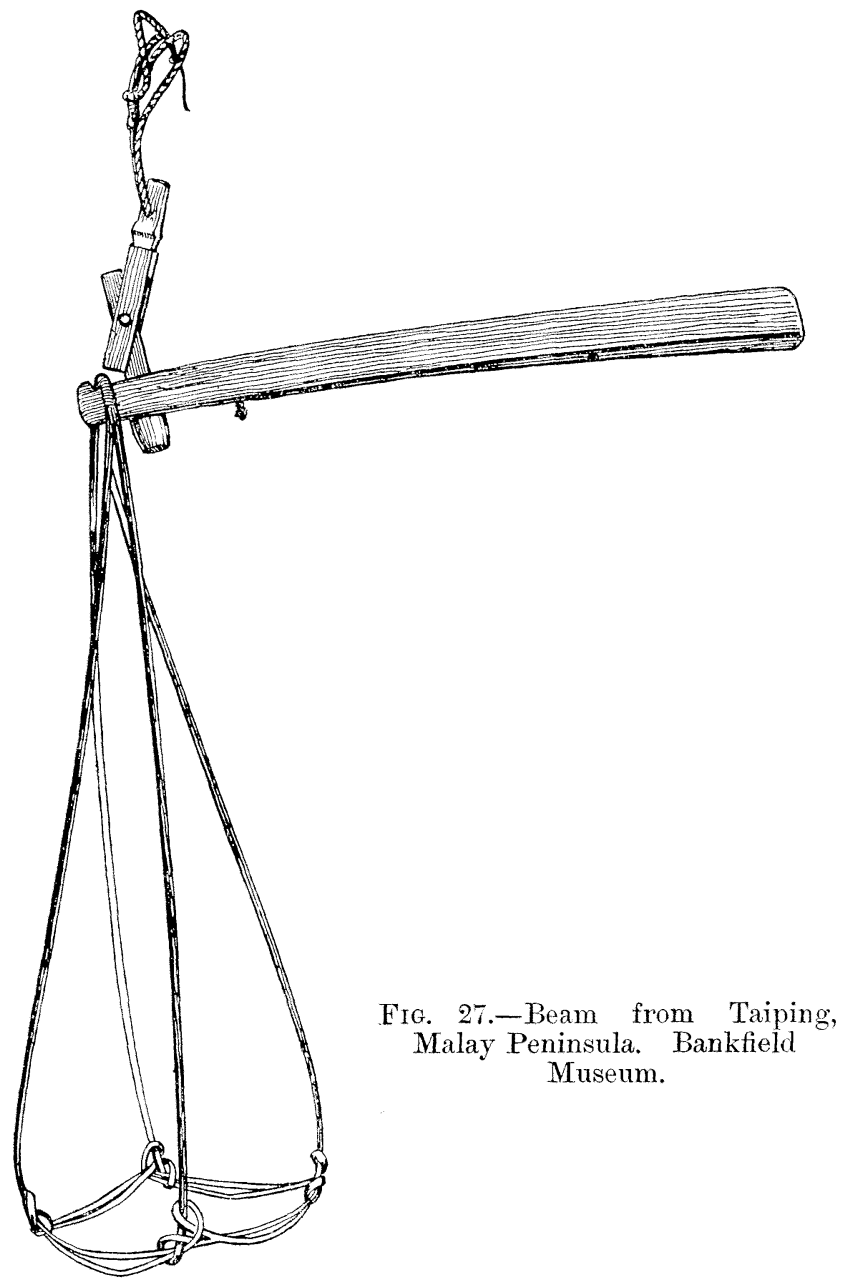

Fig. 27 represents a large bismar from Taiping, Malay Peninsula. It consists of a beam A, Fig. 28, the fulcrum post B, and the support C. When the left-hand side of the support $\mathrm{C}$ corresponds to the marks $\mathrm{N}$ on top of $\mathrm{B}$ it indicates the measure of the load.

This bismar is used for weighing padi (unhusked rice), and according to information given to me by Mr. Leonard Wray is graduated by putting a known 
quantity of padi in a basket which forms the scale pan, and then cutting a notch in the wood showing the angle the beam makes with that load. This example is graduated to weigh gantangs-a Malay gantang closely corresponding to an English gallon measure (4:5 litres). It should be borne in mind that a gantang is not a weight but a measure. This instrument is not known in the provinces of Selangor and Negri Sembilan. There are fancy letter weighing scales, Fig. 29, used in England, made on the same principle as this. Mr. Wray also informs me that in the Taiping Museum, Perak, there is a steelyard similar to this, but larger, which is provided with a wooden weight which is movable along the beam in the same way as in the Chinese steelyard. "There are four or five marks on the top of the beam to show where to put the string of the weight, but there are no figures to indicate the weight." This specimen appears to connect bismars with steelyards.

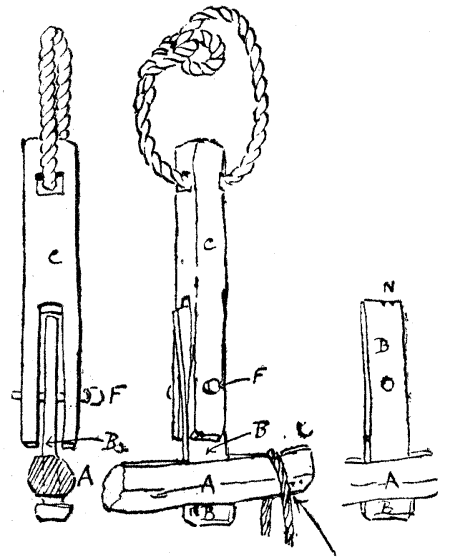

FIG. 28.

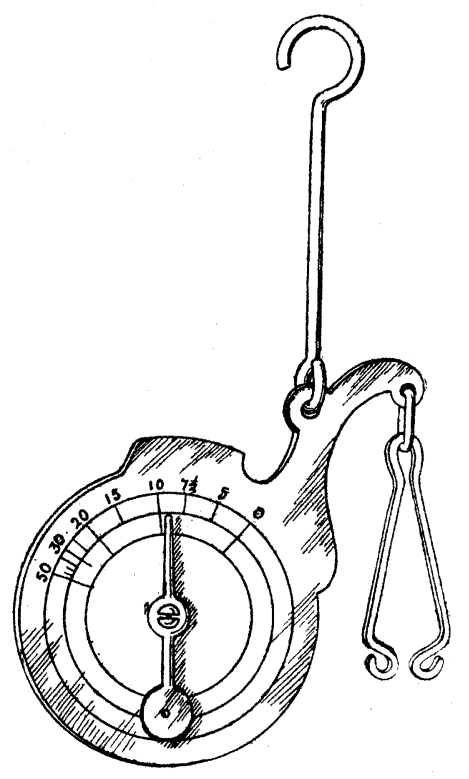

FIG. 29.-French letter - weighing scale. In use in 1869. Bankfield Museum. $\frac{1}{2}$ diam.

The bismar from Perak, Malay Peninsula, shown in Fig. 30, is made of a stout piece of wood $495 \mathrm{~mm}$. long, $38 \mathrm{~mm}$. diameter at the thick end, and $26 \mathrm{~mm}$. diameter at the thin end. Equilibrium (Eq), Fig. 31, is $275 \mathrm{~mm}$. from the thick end; the basket or pan is attached at a point $70 \mathrm{~mm}$. from the thin end, and between this end and $\mathrm{Eq}$ are 6 badly made notches at irregular intervals instead of at proportionately decreasing periods. For instance, the distance between Eq and $\mathrm{G}$ is $37 \mathrm{~mm}$; $\mathrm{G}$ and $\mathrm{H}, 27 \mathrm{~mm}$.; $\mathrm{H}$ and $\mathrm{K}, 13 \mathrm{~mm}$.; $\mathrm{K}$ and $\mathrm{L}, 10 \mathrm{~mm}$. $\mathrm{L}$ and $\mathrm{M}$, $14 \mathrm{~mm}$. ; and $\mathrm{M}$ and $\mathrm{N}, 11 \mathrm{~mm}$. 


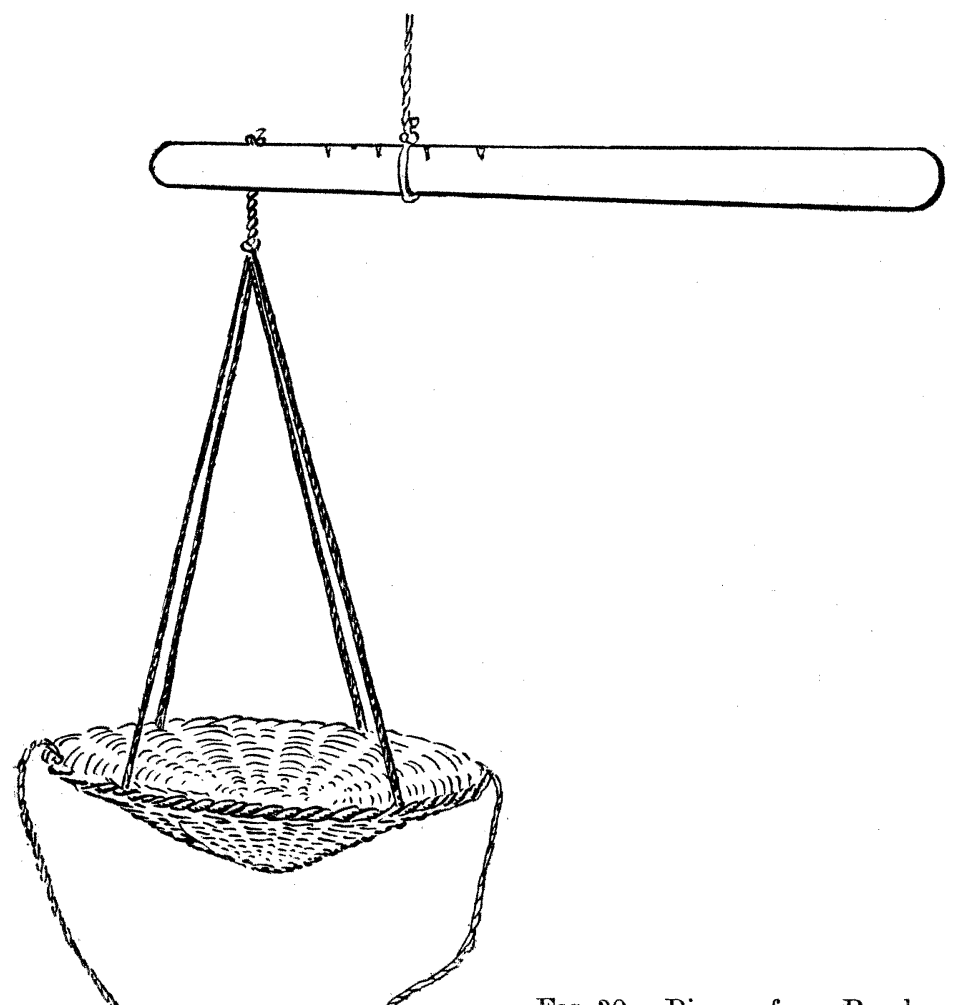

Fig. 30.-Bismar from Perak. Bankfield Museum.

$\circ$
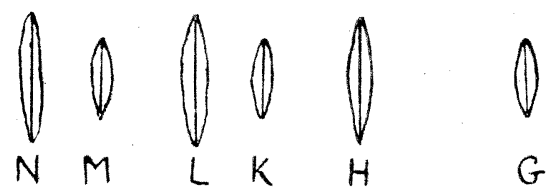

$G$

$E_{Q}$

Fig. 31.--Scale on bismar, Fig. 30.

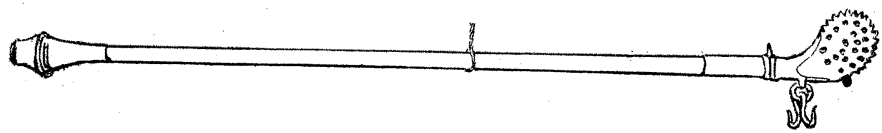

Fra. 32.-Malabar bismar. Bankfield Museum. For details of scale see Fig. 33, Pl. XXIV. 
The weights carried are

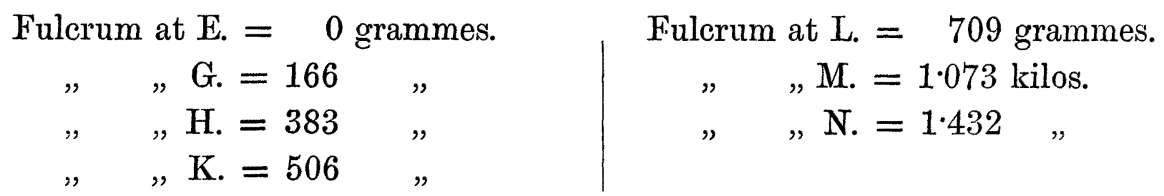

The unit is $1,432 \div 6=238$, which is neither a fraction nor a multiple of a kati, and may possibly be some purely local measure. But I am inclined to think that the weight at G, 166 grammes, is intended to be 189 grammes, or half a tahil, and at $H, 378$ grammes, or one tahil, and after this the scalemaker has got hopelessly wrong.

The Malabar bismar, Fig. 32, in Bankfield Museum, is somewhat different from that described by Mr. Thurston below. It has not the two regulating pins, and the divisions do not appear to be the same-the subdivisions being very irregular. Length, $700 \mathrm{~mm}$. The dots of the scale look very much like Chinese work. The supporting string (the movable fulcrum) cannot be moved easily, as when pushed along that part of the string which goes round the beam is apt to twist and stick. It weighs as follows. (See Scale, Fig. 33, Plate XXIV) :-

Fulcrum at $\mathrm{A} .=158$ grammes.

$$
\begin{array}{ll}
, & , \text { B. }=768 \quad, \\
, & , \text { C. }=1.587 \text { kilos. } \\
, & \quad \text { D. }=2.268 \quad "
\end{array}
$$

Fulcrum at E. $=3.827$ kilos.

$$
\begin{aligned}
& \quad, \quad \text { F. }=6.537 \quad ", \\
& ", \quad \text { G. }=8.165 \quad,
\end{aligned}
$$

The unit will be $8 \cdot 165 \div 7=1.166$ kilos. $=100$ tolas. It weighs up to 50 palams $(100$ palams $=35$ lbs. $=15 \cdot 867$ kilos. $)$ or 700 tolas $(14$ tolas $=1$ palam $)$.

This Indian bismar is thus described by Mr. E. Thurston :- " In Malabar there is used for weighing an instrument fashioned on the principle of the Danish steelyard. The yard, which is made of a hard wood, is about 4 feet long, and tapers from about $1 \frac{1}{8}$ inch in the middle to $\frac{3}{4}$ inch at the ends. It is finished off at the heavy end with a loaded brass finial simply ornamented with concentric rings, and the hook end terminates in a piece of ornamental brasswork, resembling the crook of a bishop's pastoral staff. The sliding fulcrum is simply a loop of coir (coconut fibre) string. The graduation marks, which are not numbered, are small brass pins let into the upper surface of the yard along the middle line, and flush with it. The principa] graduations are each made of five pins disposed in the form of a small cross, and single pins serve for the intermediate graduations. Corresponding to each graduation mark on the upper surface of the yard there is a pair of brass pins on the middle line of each side, the pins of each pair being at a distance apart just sufficient to allow the string of the loop to lie between them. The object of these pins is to ensure that, when the instrument is in use, the loop may be accurately in a vertical plane through the graduation mark. The unit of weight employed is the palam of about 14 tolas, and the instrument is graduated from 1 to 100 palams (about $35 \mathrm{lbs}$. $=15.87$ kilos.). The last three graduations 
representing 80, 90, and 100 palams, come upon the brasswork, and are marked by notches instead of pins. The graduation, corresponding to 100 tolas, has, in addition, a brass point about $\frac{1}{2}$ inch long, resembling the tongue of a small balance. The whole instrument is ornamental in design, and for a weighing machine of this class is fairly accurate, the sensibility being large on account of the considerable length of the yard.

"In a more simple form of weighing beam, used by native physicians and druggists in Malabar, the bar is divided into kazhinchi (approximately tolas) and fractions thereof,' and the pan is made of coconut shell." (Bulletin, Madras Government Museum, 1901, vol. iv, No. 2, p. 125.)

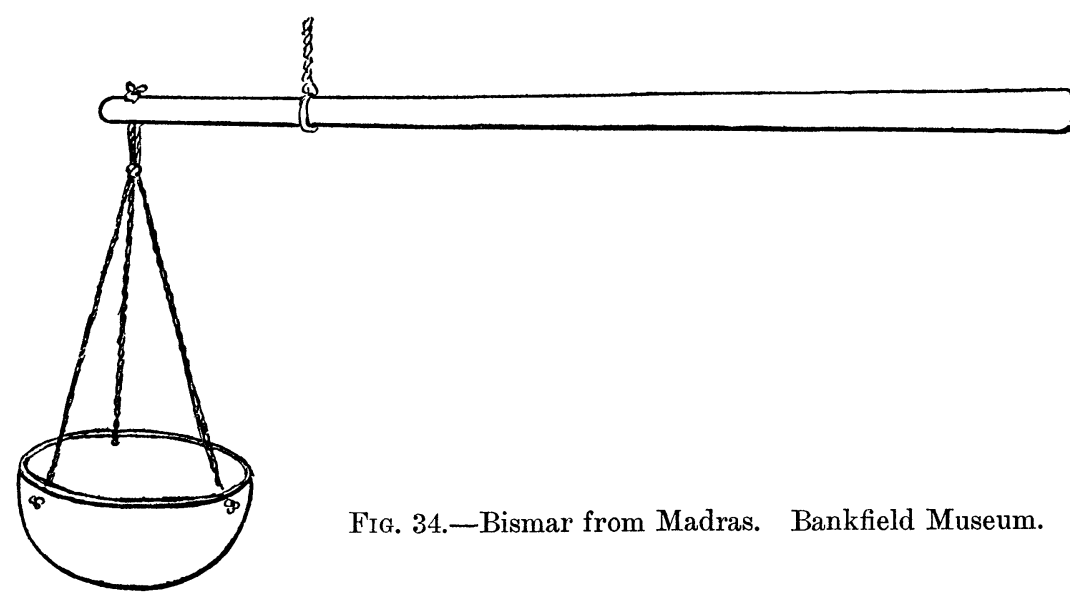

Fig. 34 illustrates a bismar with coconut pan from Madras. Length of beam $596 \mathrm{~mm}$. It weighs out as follows:-

Fulcrum at E. $=0$ grammes.

$$
\begin{array}{lll}
", \quad & a=69.0 \\
, \quad & \quad, \quad b=84.0
\end{array},
$$

so the unit is $130-69=61 \div 6=10 \cdot 2$ grammes, but if the divisions represent tolas, then the unit should be $11: 3$ grammes.

Fig. 35 illustrates a bismar from Biserat, Patani, Malay Peninsula, brought home by Mr. W. W. Skeat, for weighing cotton or tobacco; its beam is $320 \mathrm{~mm}$. long and it is provided with two fulcrums, one to weigh half a kati and one to weigh 1 kati.

It forms a sort of connecting link or point of departure between steelyards and bismars, for it has fixed fulcrums but no travelling poise.

Fig. 36 shows a bismar brought from the same district by the same explorer, used for weighing prawn condiment (blachan). Length of beam $362 \mathrm{~mm}$. It is provided with three not,ches and weighs 60,120 , and 180 grammes respectively. 

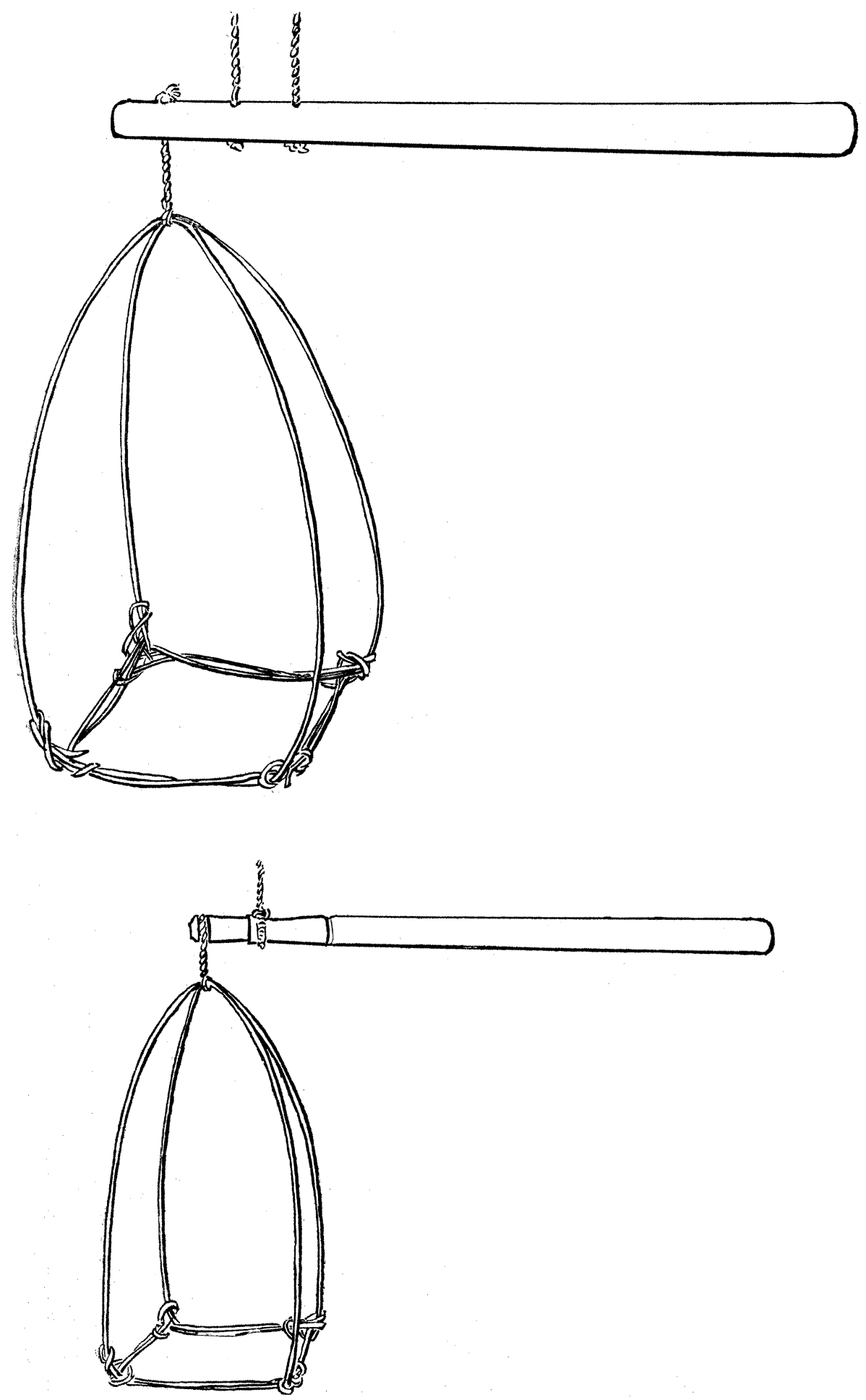

Figs. 35 and 36.-Bismars from Patani, Malay Peninsula. 
For the sake of comparison I give an illustration, Fig. 37, of an English bismar now in the museum of the Hall i' th' Wood at Bolton, by kind permission of Mr. Thomas Midgley, the Curator. Length, $540 \mathrm{~mm}$. The scale is made by means of headless nails driven into the beam: their position is not in accord with the amounts weighed in lbs., pointing perhaps to drying and contraction of the wood, but more probably to the dotting being originally incorrect or relating to some local weights in use. In European bismars the scale is placed underneath the beam, but in Oriental ones it seems to be always on top.

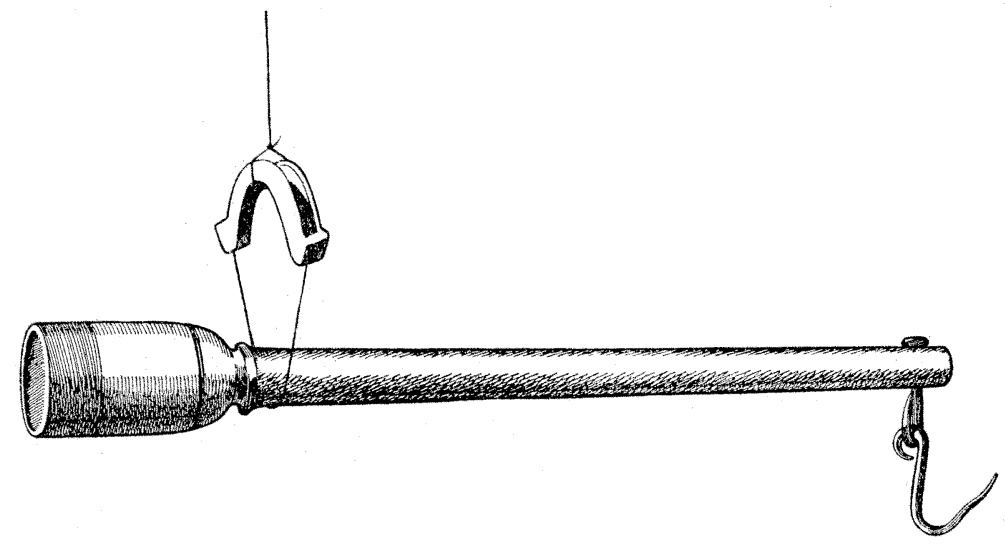

Fig. 37.-English bismar. Hall i' th' Wood Museum, Bolton.

Beyond occasional references I have not been ablë to find anything much written about steelyards, and of bismars there appears to be, with one exception, as great a dearth of literature as there is of steelyards. The one exception is a notable one. It is a very interesting and well-illustrated paper by Herr $\mathrm{H}$. Sökeland, published in the Verhandl. d. Berliner Anthrop. Ges., meeting of May 19th, 1900. An anonymous translation of this paper appeared in the Smithsonian Rep. for 1900, pp. 551-64, Washington, under the heading "Ancient Desemers or Steelyards." This is an unfortunate heading, for as Herr Sökeland emphasizes the difference between the bismar (desemer) - the instrument with the movable fulcrum-and the steelyard-the instrument with the movable poise-it is incorrect to give these instruments alternative nomenclature. Apart from the footnotes, the translator adds matter which does not appear in the original, but which the reader is naturally induced to believe is there. As to the origin of the balance and bismar, Herr Sökeland thinks both inventions date from primitive times and were made by different peoples at different dates, also that the invention was easily made. He thinks the idea was obtained from the yoke of a carrier who would soon learn that to get a balance both ends must be equally weighted. This may be so, but anthropologists, who know how very slowly progress is made, are not likely to agree with him that the invention was an easy one. It is difficult to judge whether the bismar, steelyard, and balance had more than one origin each, VOL. XLII. 
for the bismars as well as the other two instruments must of necessity be much alike in their primitive form, until such times when a higher civilization introduces variations and complexities. The bismar is the simplest of the three, and it is possible that the steelyard and the balance grew out of it. That there is a close relation is very evident-it cannot be otherwise - and two specimens in the British Museum confirm this. The one, Fig. 38, represents a weight measurer consisting of a beam with fulcrum in the centre, with a pan at one end and a fixed weight at the other. To all intents and purposes it looks like a balance

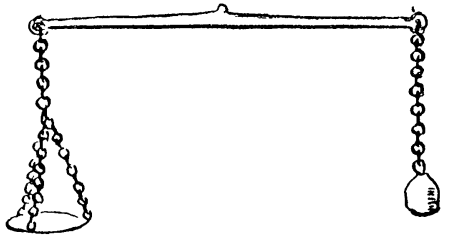

Fig. 38.-Roman bismar.

British Museum. with one of the pans removed, but it is the most primitive form of bismar with fixed fulcrum and fixed poise. The other instrument, Fig. 39, is a balance with notches cut on the one arm of the beam into which fits a movable poise, so that it is a balance and steelyard in one.

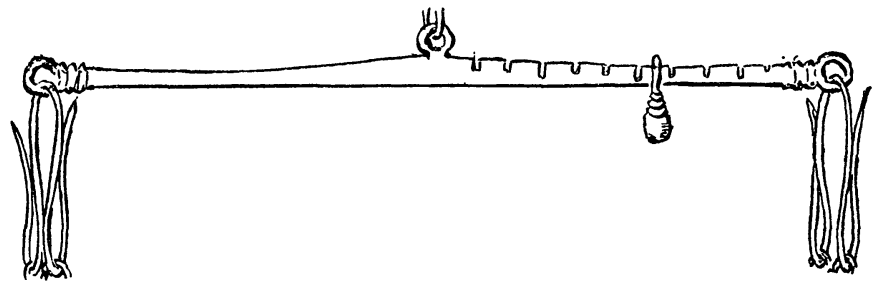

Fra. 39.-Roman balance. British Museum.

Herr Sökeland gives illustrations of and refers to bismars in Germany, Russia, Bhutan, Thibet, "the Himalayas," as well as to the Roman bismar, but he does not mention the bismar as formerly in use in England, nor does he refer to the Scandinavian instrument. In connection with the use of the latter in the Faroes, Mr. N. Annandale has some interesting remarks. He writes of a "Wooden weighing beam with fixed weights_a characteristic Scandinavian implement, which reappears in a slightly different form after a gap of much intervening territory, in regions so remote as India and Siam. The weight it records is usually so inaccurate that its employment in commercial transactions has long been forbidden by Danish law, but in the Farish villages most of the households still use it, for their own satisfaction, in preference to any more elaborate type of steelyard or other weighing machine" (p. 20). “. . . In the Faroes the machine almost invariably employed in weighing is the wooden beam to which reference has already been made; but in Iceland, where people ridicule the idea of a wooden beam, a steelyard with movable weights, which may in rare cases be made of stone, is used" (p. 192). ". . . In the Faroes the indicator of the weighing beam is frequently a semicircle of sheep's horn suspended by a piece of whale's sinew" (p. 192, The Faroes and Iceland, London, 1905). 
As we have shown, the bismar is also found in the Malay Peninsula and Madras; it is probably also in use in Southern India.

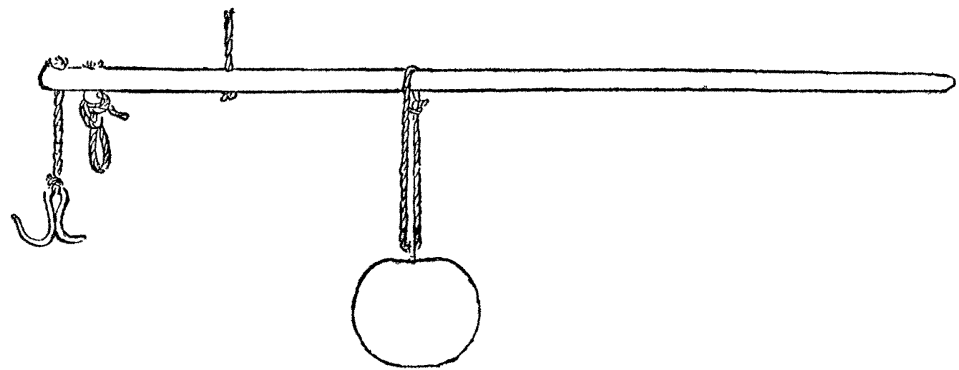

Fig. 40.--Steelyard from Yarkand. Indian Museum, South Kensington.
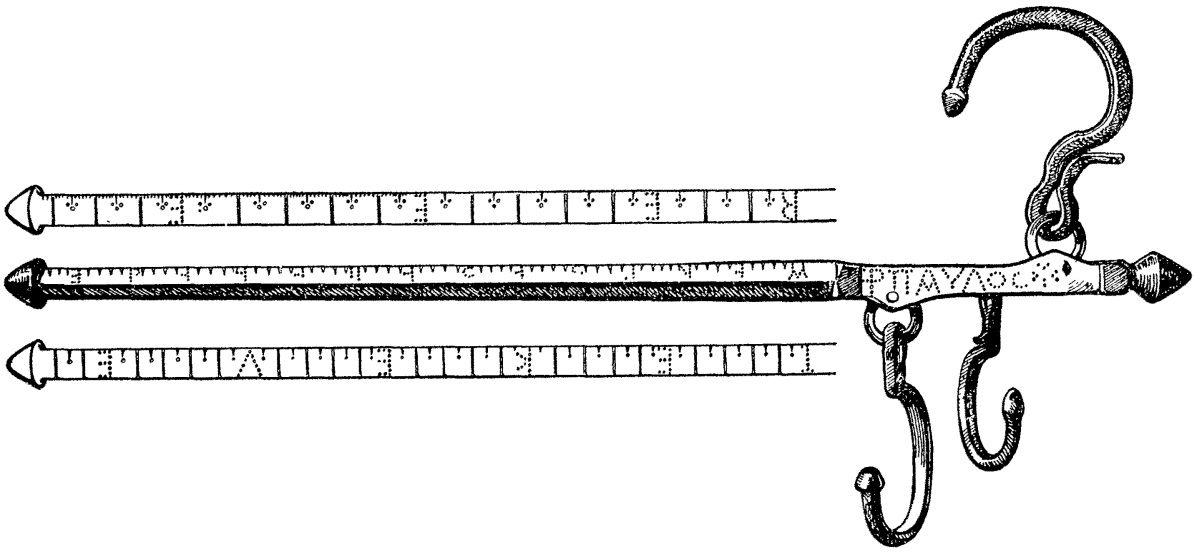

Fig. 41.-Roman steelyard. In the possession of Professor W. Flinders Petrie, F.R.S.

A Yarkand steelyard shown (by kind permission of Mr. Stanley Clarke) in Fig. 40, in the Indian Museum, South Kensington, is of the usual Chinese type. It is provided with two scales (rows of dots) on a wood beam $73 \mathrm{~cm}$. long; it has also a granite poise weighing approximately 1.37 kilogrammes.

Mr. W. Woodville Rockhill reports the steelyard from Thibet. He says that the Chinese money scales (Jama) are used by the Thibetans and in Mongolia; he illustrates the ordinary Chinese steelyard above described, and also a rough copy of such an instrument made in Thibet at Taichinar Tsaidam: "In the latter the wooden beam is roughly indented to indicate ounces, tenths, and hundredths of ounces (in Thibetan called srang, djo, and karna), instead of a brass tray, one of buckskin suspended by horse hairs is used, and the weight is a bullet roughly flattened out. These scales fit in a wooden trough roughly whittled out by a knife" ("Notes on the Ethnology of Thibet," Report U.S. Nat. Mus., 1893, p. 719). Anything cruder than the Thibetan copy can hardly be imagined.

As regards the steelyard (and presumably the bismar), Dr. L. W. King

Frg. 41A.-Chain belonging to steelyard Fig. 41 . 
informs me the Babylonians did not possess it; nor, according to Professor Flinders Petrie, did the Egyptians possess it until Roman times. The Greeks seem to have had the ordinary two-pan balance only (Brit. Mus. Guide to Greek and Roman Life, London, 1908, p. 149). The Romans had various forms. The one from

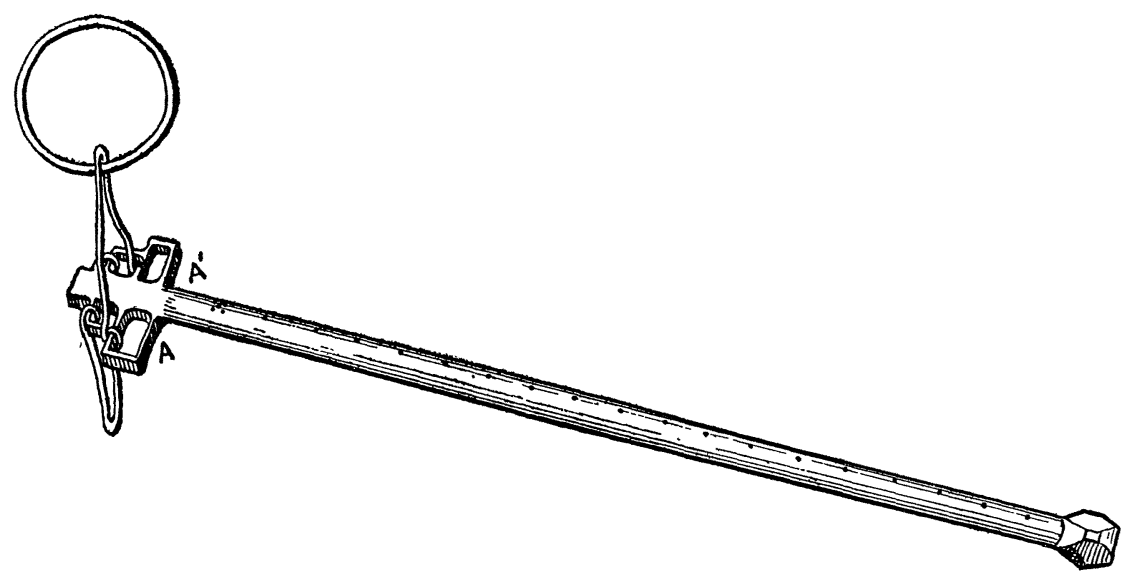

Fia. 42.-Roman steelyard in the possession of Professor Flinders Petrie. Length $223 \mathrm{~mm}$. It is probable there was another link at $\mathrm{A} \mathrm{A}^{\prime}$.

Egypt, illustrated in Fig. 41, in the possession of Professor Flinders Petrie, is provided with a special arrangement of double chains and hooks, Fig. 42, apparently for use with heavy articles; the poise is missing. He also possesses a beautifully finished Arabic steelyard, probably fourteenth century, shown in Fig. 43, with details, Figs. 44 and 45.

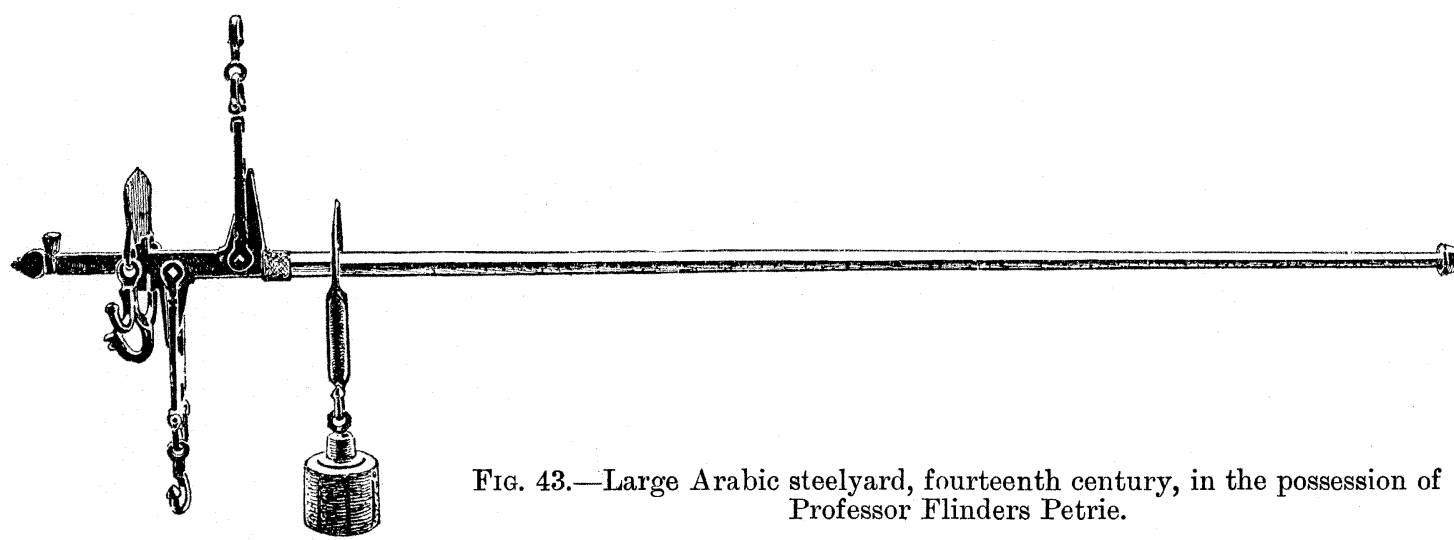

The South European steelyards, while they cannot, of course, differ in principle from the extreme Oriental article, differ very considerably in make, being generally of iron (or steel?). 


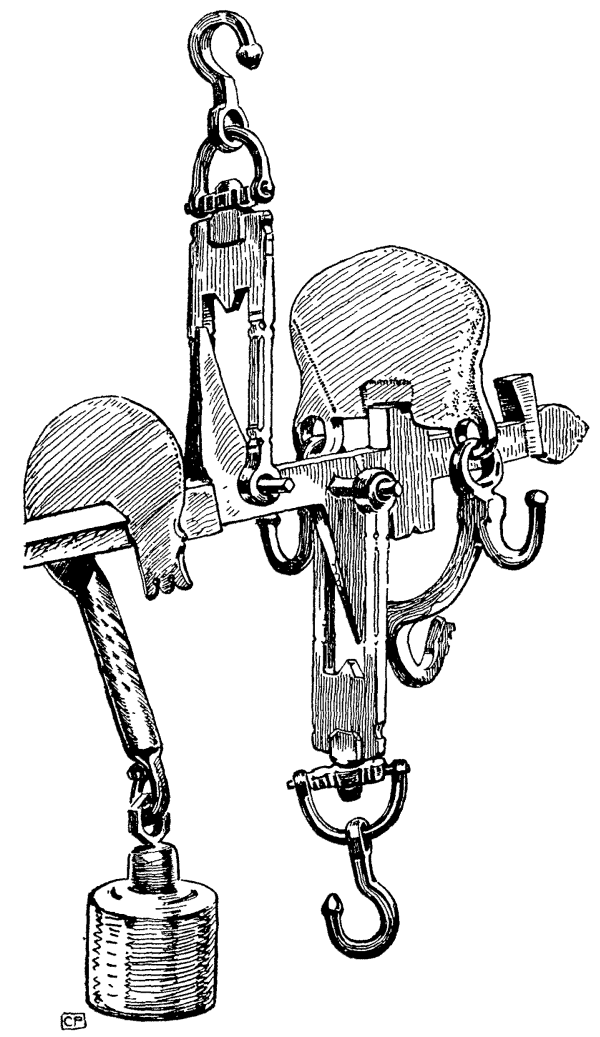

FIG. 44.-Details of Fig. 43.

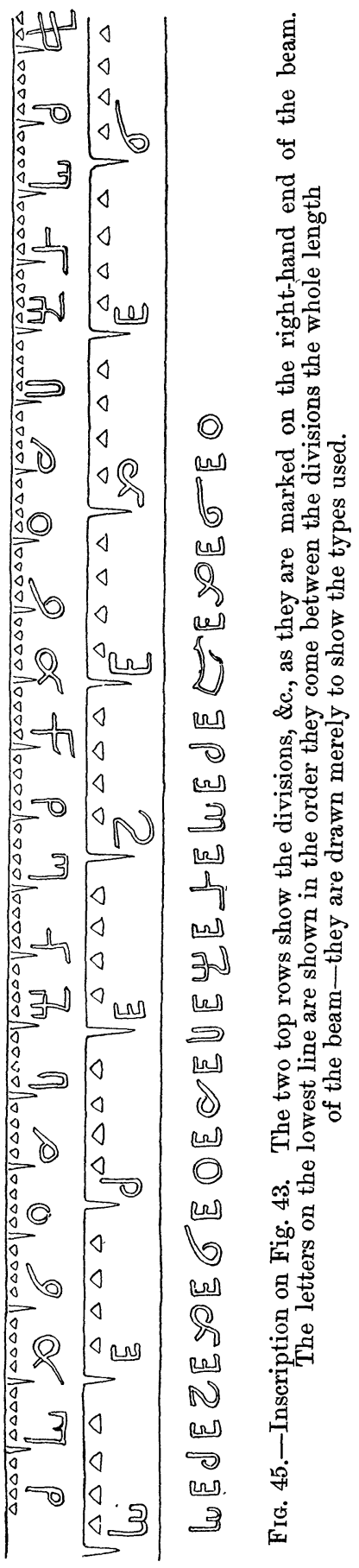




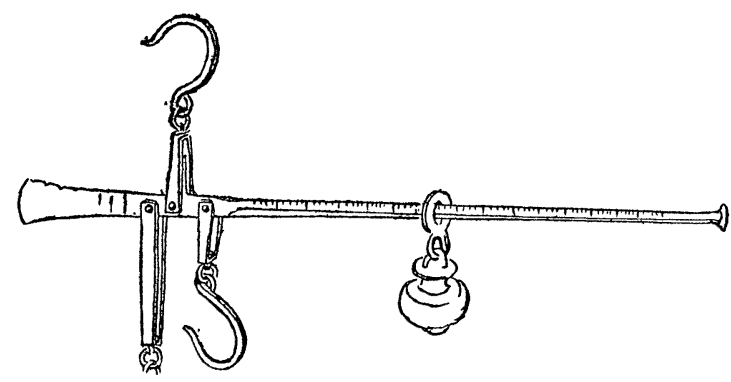

Fig. 46.-Old steelyard from North Italy. Bankfield Museum. Length, $22 \mathrm{~cm}$.

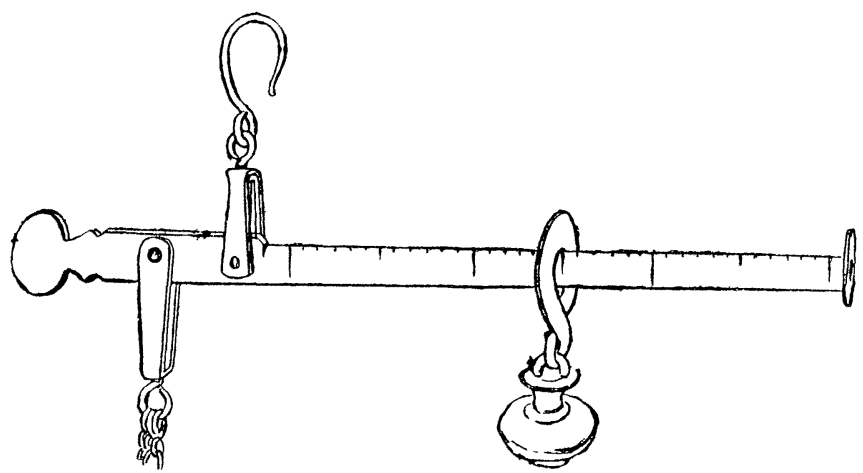

Fig. 47.-Old steelyard from North Italy. Bankfield Museum. Length, $28 \mathrm{~cm}$.

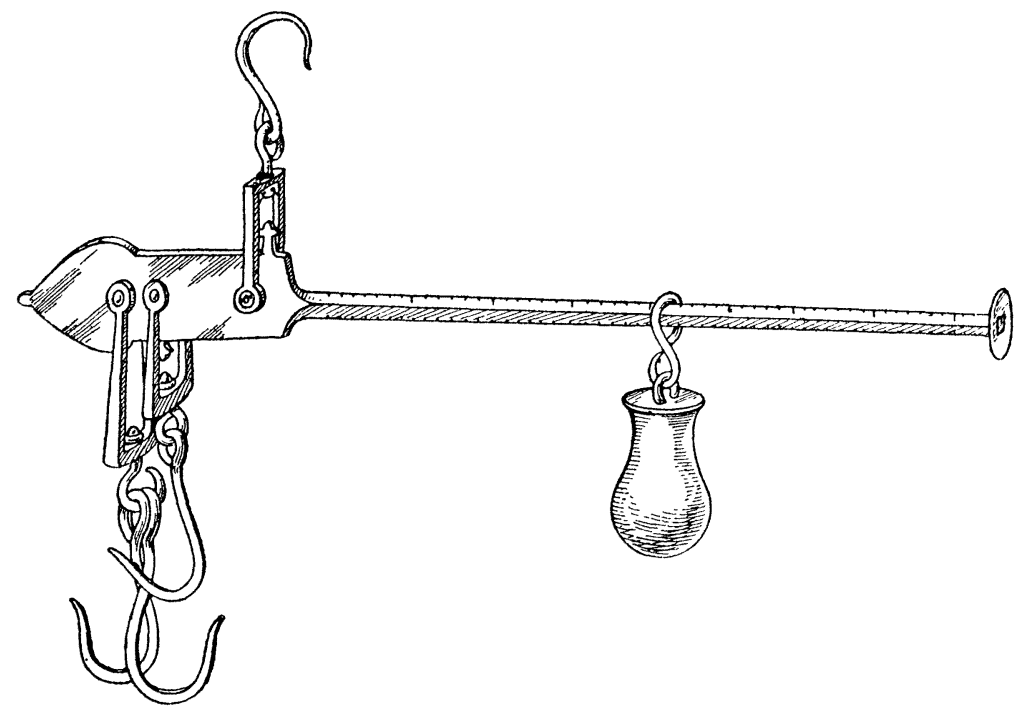

FIG. 48.-Old steelyard from North Italy. Bankfield Museum. Length, $37 \mathrm{~cm}$. 
In Figs. 46, 47, and 48 we have illustrations of three modern steelyards from North Italy, considerably the worse for wear, in which the fulcrum is placed so low that the tendency to upset is very marked. This class of balance is at the present day largely of English make. The manufacturers are careful to specify in their catalogues that it is not permissible to use such steelyards in England.

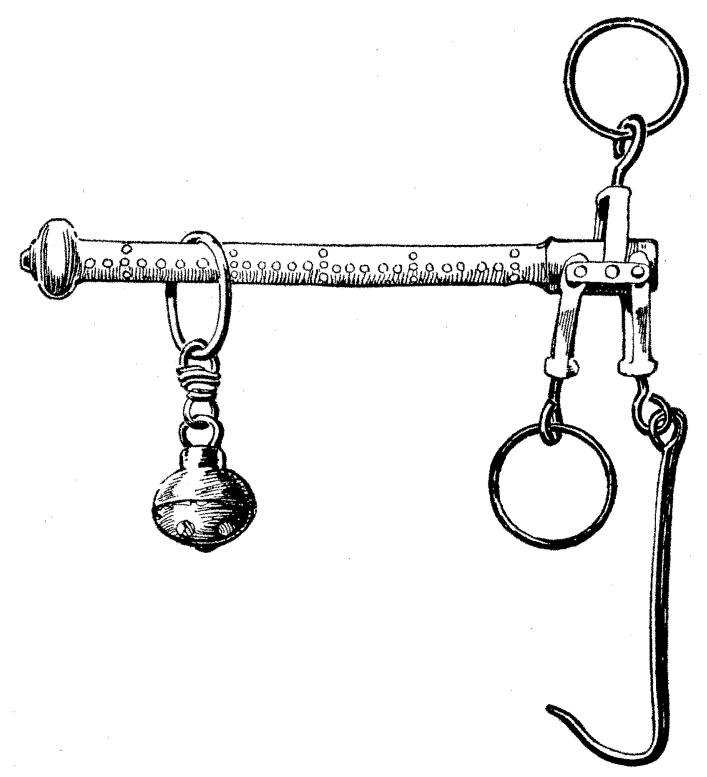

Fra. 49.-Eighteenth-century English steelyard. Horniman Museum. Wood beam $21 \mathrm{~cm}$. long.

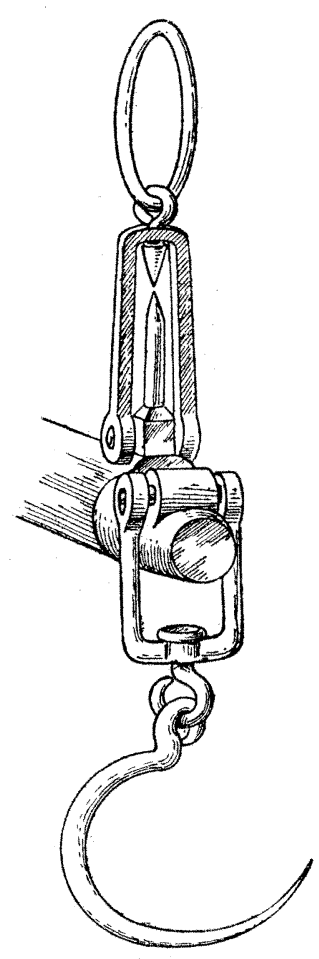

Fig. 50.--Details of Malay steelyard. Bankfield Museum.

A seventeenth-century English steelyard, Fig. 49, now in the Horniman Museum (illustrated by kind permission of Dr. Harrison), has the turnover arrangement similar to that of a Chinese-made steelyard from Perak, Fig. 50, in Bankfield Museum. In the engraved certificate which is supplied to successful students by the Pharmaceutical Society, the right-hand figure, facing the reader, appears to be holding a steelyard in its hand.

Although the bismar was largely used in England, I have not met any old paintings or prints illustrating one. In Holbein's Archangel Michael the angel is making use of an ordinary two-pan balance in which to weigh human beings, and in his portrait of George Gisse, merchant, of the Steelyard, London, in the Royal Museum, Berlin, an ordinary balance with two triangular pans is shown. So, too, while the steelyard may almost be said to have its home in the East, there are numerous references and illustrations showing the use there of the ordinary 
two-pan balance. Archdeacon J. H. Gray gives a plate representing a Chinese moneychanger with the two-pan balance (China, London, 1878, ii, p. 83), and De la Loubère refers to weighing "much alloyed silver in one of the pans of a balance and the silver money in the other pan" (Descrip. du Royaume de Siam, Amsterdam, 1713, i, p. 221).

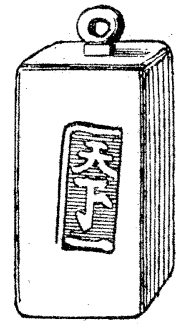

Fra. 51.

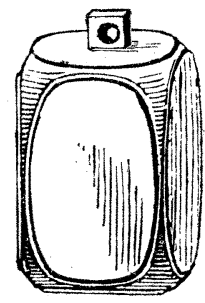

Fig. 52.

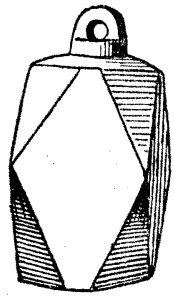

FIG. 53.

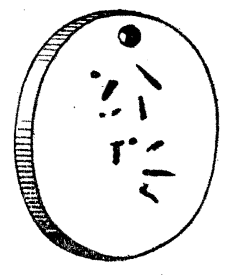

Fig. 54.

Figs. 51-54.-Poises of Chinese steelyards in British Museum.

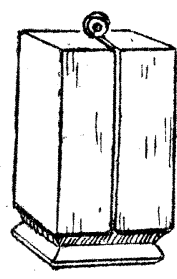

Fig. 55.

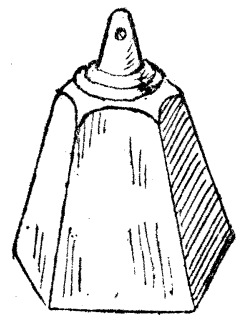

Fig. 56.

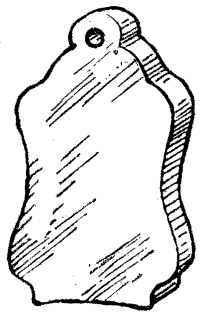

Frg. 57.

Figs. 55-57.-Poises of Chinese steelyards sketched at missionary exhibitions. Fig. 55 is a double-power poise.

As to the word "steelyard" the late Mr. Thomas Wright, in his work on Uriconium, p. 308, indicates that it is probably derived from the word stelleere, and quotes Cotgrove's French Dictionary. Professor Skeat, Notes and Queries, 4th series, 1903, p. 272, points out that neither the word steel nor yard has anything to do with the origin of the name steelyard. He thinks that it may be derived from the Latin hastile, the shaft of a spear. Since then there has been another explanation put forward in a little-known book entitled the Strife of the Scales, the author of which, the late Mr. J. A. Kingdon, was a Past Master of the Worshipful Company of Grocers. ${ }^{1}$ The book deals with the legislation which was intended to abolish the Danish bismar and to give its place to the steelyard. In speaking of the old auncel (or bismar) he says that:

"In the year 1458 two women were reported to the Dean and Chapter of St. Paul's, each of them having in their possession unum auncellum, which laid them

1 The first edition consisted of fifty-nine pages, and it appears only twenty copies were printed off ; at the foot of the title-page are the words "Privately printed for J. A. Kingdon." The second edition, published by Rixon \& Arnold, 29, Poultry, London, consisted of seventyeight pages, and only 100 copies were printed. 
Fig. 1.-Chinese steelyard with double-power $p$ Fig. 2.-Chinese steelyard. Bankfield Museum Fig. 3.-Japanese steelyard. Bankfield Museu FIG. 4.-Anamite salesman with steelyard. G. Fig. 5.-Poise of steelyard Fig. 14. British M

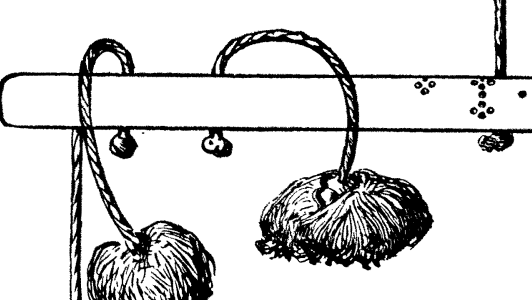

$$
\text { FIG I. }
$$

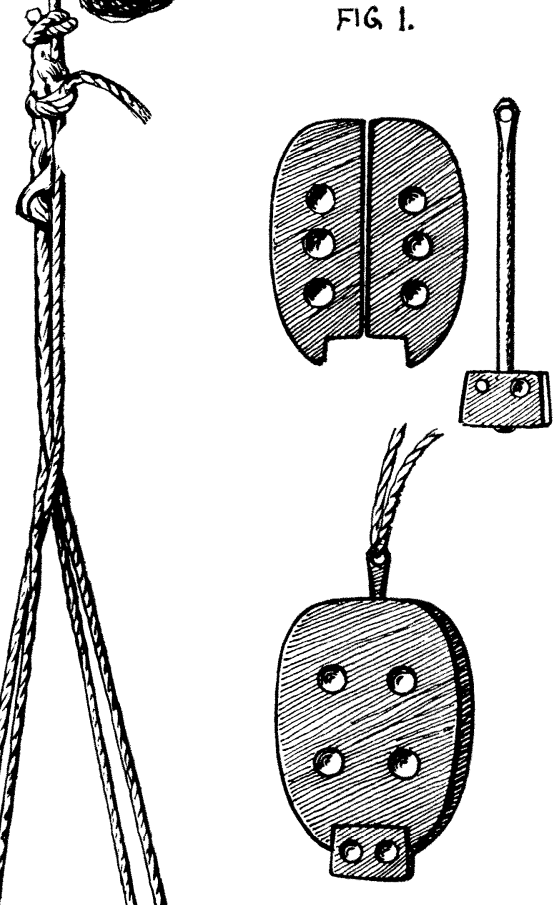


Ird with double-power poise. In the possession of Mr. E. C. S. George, C.I.E. ard. Bankfield Museum. Length, $226 \mathrm{~mm}$.

yard. Bankfield Museum.

nan with steelyard. G. Knosp. Globus, vol. 1xxx, Feb. 1st, 1902, p. 123. ard Fig. 14. British Museum.

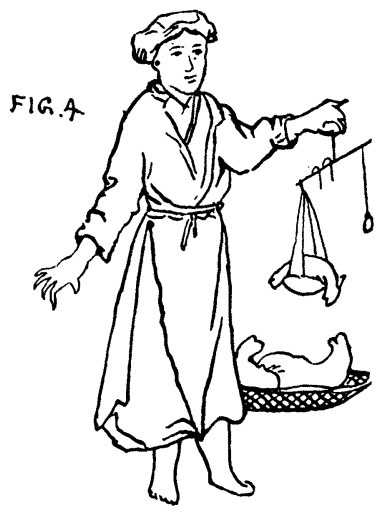

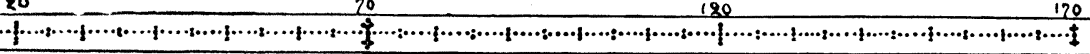

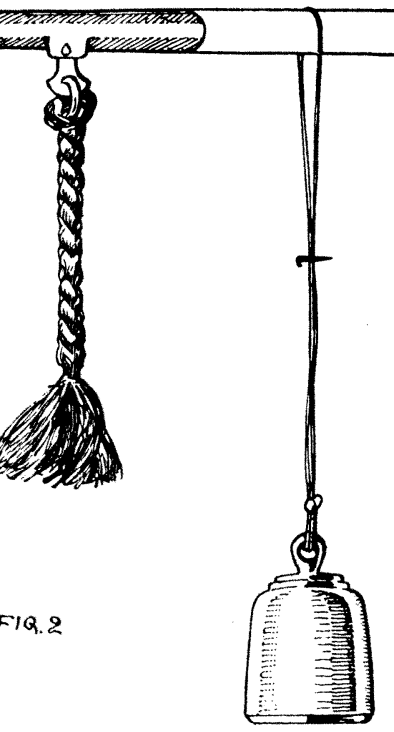




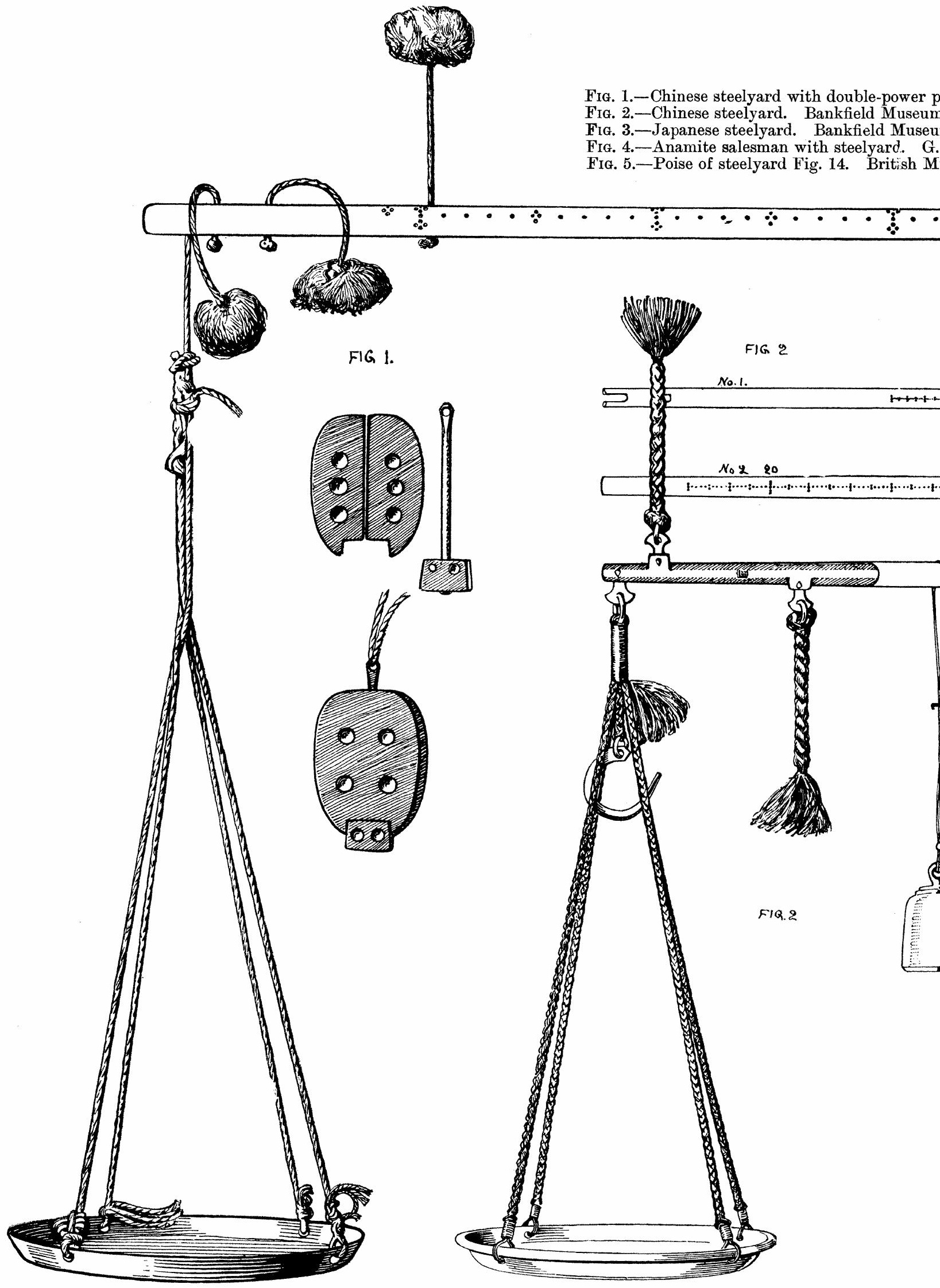


ird with double-power poise. In the possession of Mr. E. C. S. George, C.I.E. ard. Bankfield Museum. Length, $226 \mathrm{~mm}$.

yard. Bankfield Museum.

nan with steelyard. G. Knosp. Globus, vol. 1xxx, Feb. 1st, 1902, p. 123.

ard Fig. 14. British Museum.

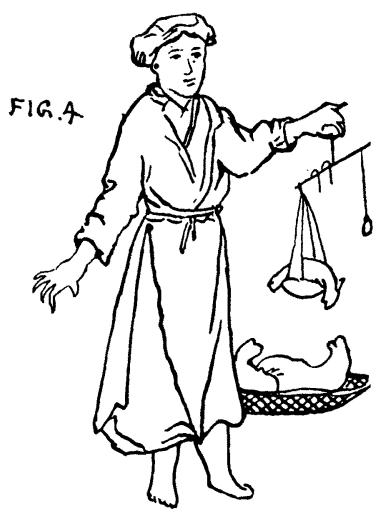

$G$

$\cdots \cdots \cdots \cdots$

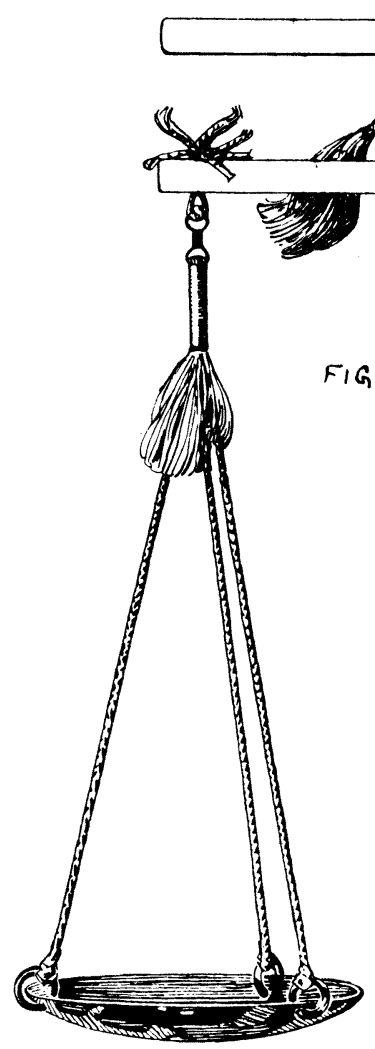

10

20

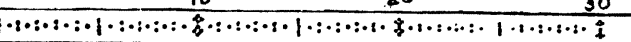

FIG.3

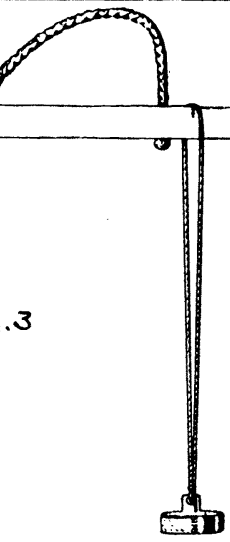

FIG 5

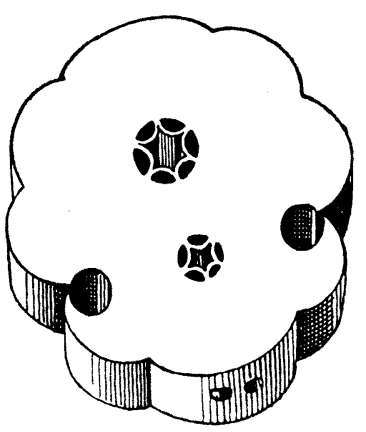




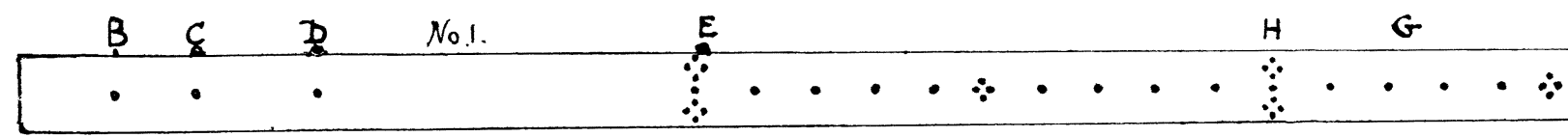

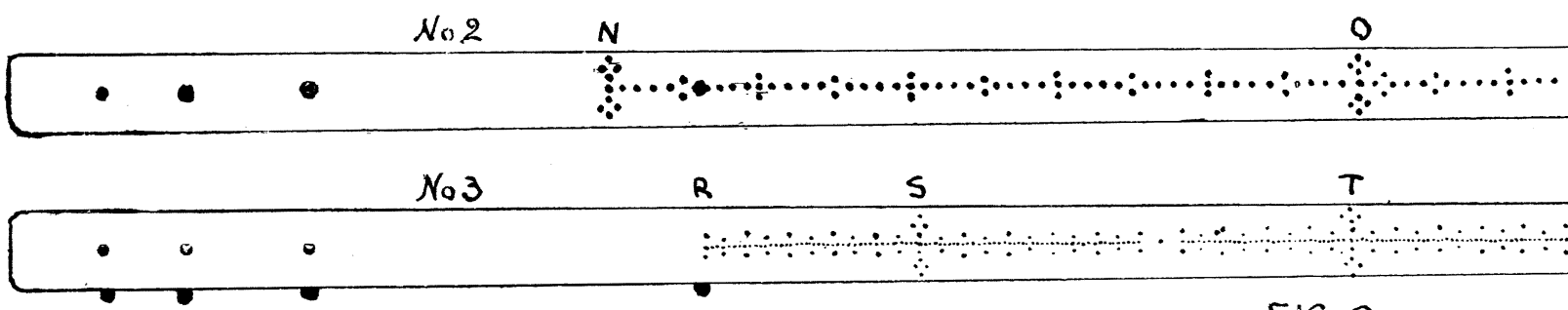

\section{FiG.6}

Fig. 6.-Beam and scales (full size) o

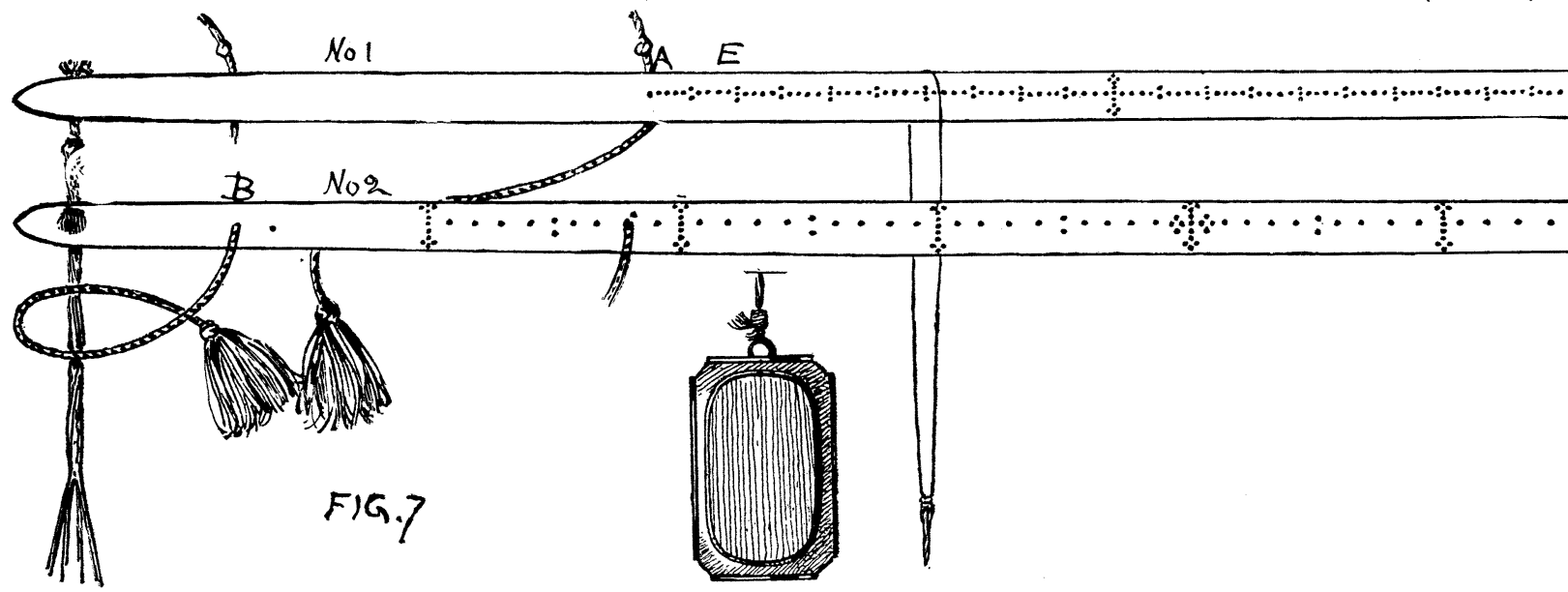

FIG. 7.-Chinese steelyard. Bankfiel
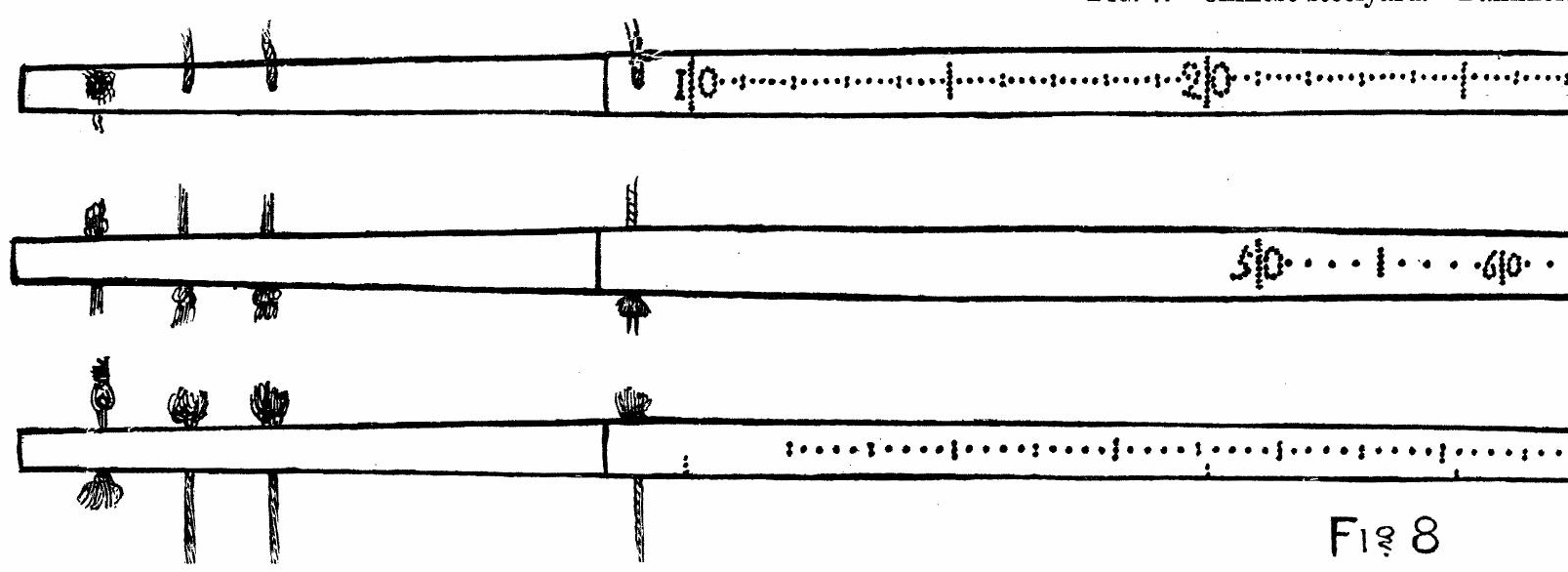

Fig. 8.-Beam and scales of a Chinese steelyard, with European cyphers ; it has an
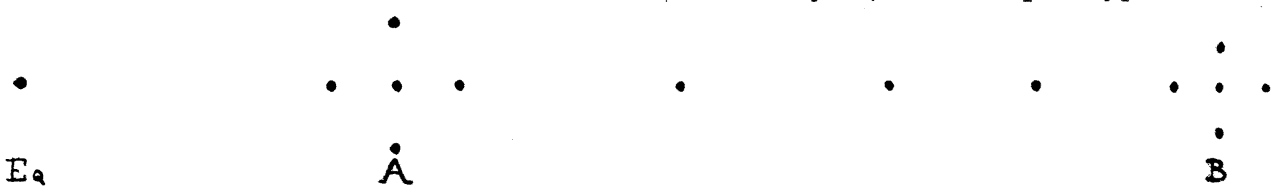

FIG. 33.-Scale on Malabar 
open to ecclesiastical censure. What is to the present purpose is the wording of the Archbishop's denunciation, as it helps to determine what the auncell really was. The word is used in the document in connection with scheft or pounder, names of Danish instruments of the bismar order of construction ; and this suggests that it was really a bismar, which, when Norman rule came in upon London trade, received a Norman name denoting its nature, a one-armed, single-scaled weighing. lever, lanx, lance, lancella, and in vernacular auncel, a meaning which the Saxon or Danish word would not convey to the new rulers. It was not a stalier or stilliard, although that also was a lanx, for the word statera, which needed no change by the Normans, stood for that; but it was different, and specially condemned by the statute by name. It was different, but in what particular feature different its new name did not explain. The word statera would be known to the Normans. It was Latin, and passing through the Italian stadera reached stalier stilliard, and in 1700 steelyard in English. This form of lever, as is well known, measured weights by means of a counterpoise movable along the beam or rod of the instrument. The bismar was otherwise used. In this the counterpoise was fixed and the fulcrum or swing-point was moved along the rod."

\section{Table of Weights.}

I. Chinese.

\begin{tabular}{|c|c|c|c|c|c|c|}
\hline & $1 \mathrm{Ti}(\mathrm{Li}$, Nominal Cash) & $=$ & \multicolumn{3}{|c|}{0.0378 grammes. } & \\
\hline $10 \mathrm{Ti}$ & $=1 \mathrm{Hun}$ (Sen, Canderen) & $=$ & 0.3781 & $\eta$ & & \\
\hline $10 \mathrm{Hun}$ & $=1 \mathrm{Chi}$ (Chien, Mace) & $=$ & $3 \cdot 7817$ & ” & & \\
\hline $10 \mathrm{Chi}$ & $=1$ Tahil (Tael, Liang) & $=$ & $37 \cdot 8169$ & $"$ & $=$ & $1 \frac{1}{3}$ oz. avoir. \\
\hline 16 Tahil & $=1$ Kati (Catty, Chin) & $=$ & $604 \cdot 791$ & $"$ & $=$ & $1 \frac{1}{3} \mathrm{lb}$ \\
\hline 100 Kati & $=1$ Picul $(\operatorname{Tan})$ & $=$ & $60 \cdot 48$ & kilos. & $=$ & $133 \frac{1}{3} \mathrm{lb}$ \\
\hline
\end{tabular}

II. JAPANESE.

\begin{tabular}{|c|c|c|c|c|c|c|c|c|}
\hline & & 1 Shu & $=$ & $0 \cdot 416$ & mmé & $=$ & 1.565 & $\mathrm{mr}$ \\
\hline $6 \mathrm{Shu}$ & $=$ & $1 \mathrm{Bu}$ & $=$ & $2 \cdot 5$ & " & $=$ & $9 \cdot 391$ & " \\
\hline $4 \mathrm{Bu}$ & $=$ & 1 Riyo & $=$ & 10 & \# & $=$ & $37 \cdot 565$ & ", \\
\hline 16 Riyo & $=$ & $1 \mathrm{Kin}$ & $=$ & 160 & ", & & $601 \cdot 040$ & , \\
\hline 1 Kwan & & & $=$ & 1,000 & , & $=$ & $3 \cdot 756$ & os. \\
\hline
\end{tabular}

